\title{
Stable mercury concentrations of tropical tuna in the south western Pacific ocean: An 18-year monitoring study
}

\author{
Médieu Anais ${ }^{1,}$ * , Point David ${ }^{2}$, Receveur Aurore ${ }^{3}$, Gauthier Olivier ${ }^{1}$, Allain Valerie ${ }^{3}$, \\ Pethybridge Heidi ${ }^{4}$, Menkes Christophe E. 5 , Gillikin David P. ${ }^{6}$, Revill Andrew T. 4, \\ Somes Christopher J. ${ }^{7}$, Collin Jeremy ${ }^{1}$, Lorrain Anne ${ }^{1}$
}

1 Univ Brest, CNRS, IRD, Ifremer, LEMAR, F-29280, Plouzané, France

2 Observatoire Midi-Pyrénées, GET, UMR CNRS 5563/IRD 234, Université Paul Sabatier Toulouse 3,

Toulouse, France

3 Pacific Community, Oceanic Fisheries Programme, Nouméa, France

4 CSIRO Oceans and Atmosphere, Hobart, Tasmania, Australia

${ }^{5}$ ENTROPIE (UMR 9220), IRD, Univ. de La Réunion, CNRS, Nouméa, New Caledonia

${ }^{6}$ Department of Geology, Union College, 807 Union St., Schenectady, NY, 12308, USA

7 GEOMAR Helmholtz Centre for Ocean Research Kiel, Düsternbrooker Weg 20, 24105 Kiel, Germany

* Corresponding author : Anaïs Médieu, email address : anais.medieu@gmail.com

\begin{abstract}
:
Global anthropogenic mercury $(\mathrm{Hg})$ emissions to the atmosphere since industrialization are widely considered to be responsible for a significant increase in surface ocean $\mathrm{Hg}$ concentrations. Still unclear is how those inputs are converted into toxic methylmercury $(\mathrm{MeHg})$ then transferred and biomagnified in oceanic food webs. We used a unique long-term and continuous dataset to explore the temporal $\mathrm{Hg}$ trend and variability of three tropical tuna species (yellowfin, bigeye, and skipjack) from the southwestern Pacific Ocean between 2001 and $2018(n=590)$. Temporal trends of muscle nitrogen $(\delta 15 N)$ and carbon $(\delta 13 C)$ stable isotope ratios, amino acid (AA) $\delta 15 \mathrm{~N}$ values and oceanographic variables were also investigated to examine the potential influence of trophic, biogeochemical and physical processes on the temporal variability of tuna $\mathrm{Hg}$ concentrations. For the three species, we detected significant inter-annual variability but no significant long-term trend for $\mathrm{Hg}$ concentrations. Inter-annual variability was related to the variability in tuna sampled lengths among years and to tuna muscle $\delta 15 \mathrm{~N}$ and $\delta 13 \mathrm{C}$ values. Complementary AA- and model-estimated phytoplankton $\delta 15 \mathrm{~N}$ values suggested the influence of baseline processes with enhanced tuna $\mathrm{Hg}$ concentrations observed when dinitrogen fixers prevail, possibly fuelling baseline $\mathrm{Hg}$ methylation and/or $\mathrm{MeHg}$ bioavailability at the base of the food web. Our results show that $\mathrm{MeHg}$ trends in top predators do not necessary capture the increasing $\mathrm{Hg}$ concentrations in surface waters suspected at the global oceanic scale due to the complex and variable processes governing $\mathrm{Hg}$ deposition, methylation, bioavailability and biomagnification. This illustrates the need for long-term standardized monitoring programs of marine biota worldwide.
\end{abstract}




\section{Graphical abstract}

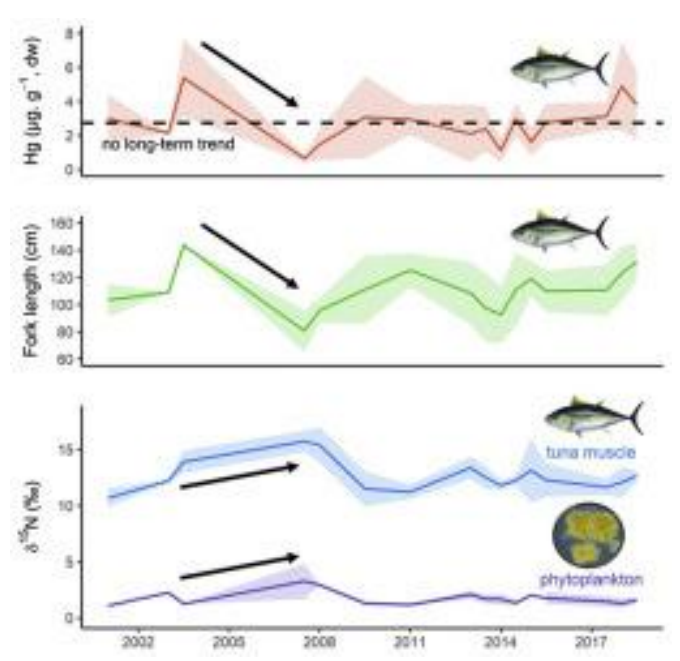

Highlights

- Long-term and continuous tuna Hg levels in the SW Pacific Ocean were investigated. Hg levels did not show any significant decadal trend but inter-annual variability. Baseline phytoplankton processes are likely to drive tuna $\mathrm{Hg}$ variability. A significant number of bigeye had $\mathrm{Hg}$ levels above food safety guideline (1 ppm, ww).

Keywords : Methylmercury, Stable isotope data, Yellowfin tuna, Bigeye tuna, Skipjack tuna, New Caledonia-Fiji region 


\section{Introduction}

Mercury $(\mathrm{Hg})$ is a widely distributed trace element of particular concern to human and ecosystem health. Its toxicological effects are strongly dependent on the physical properties of its different chemical forms (Hintelmann, 2010). Gaseous elemental $\mathrm{Hg}$ is emitted to the atmosphere through natural (volcanism and erosion) and anthropogenic (fossil fuel combustion and artisanal gold mining) processes (Pirrone et al., 2010). In open ocean regions, the dominant source of inorganic $\mathrm{Hg}(\mathrm{iHg})$ is atmospheric deposition with other inputs coming from ocean margins, groundwater, benthic sediments and hydrothermal vents (Selin et al., 2007). Only a fraction of $\mathrm{iHg}$ is naturally converted into methylmercury ( $\mathrm{MeHg}$ ), the organometallic form of $\mathrm{Hg}$ characterised by strong neurotoxicity, persistence and unique biomagnification properties in food webs. Over the past 150 years of the industrial era, anthropogenic $\mathrm{Hg}$ use and emissions have considerably modified the natural global $\mathrm{Hg}$ cycle (Selin et al., 2008). Models suggest that anthropogenic activities have increased atmospheric $\mathrm{Hg}$ concentrations and have tripled the iHg content in the global ocean surface waters (Lamborg et al., 2014), but with suspected sub-regional differences. In particular in the North Pacific Ocean, surface water $\mathrm{Hg}$ concentrations have been reported to be higher in the eastern North Pacific than in the western North Pacific (Sunderland et al., 2009). Most global models utilize ocean Hg data collected in oceanic regions from the northern hemisphere, but questions have risen about how well these models describe potential hemispherical ocean patterns with lower $\mathrm{Hg}$ concentrations reported in the southern atmosphere (Horowitz et al., 2017).

Humans are exposed to $\mathrm{MeHg}$ primarily by the consumption of marine fish, especially of top predators such as tuna (Mergler et al., 2007; Sunderland, 2007) as MeHg biomagnifies naturally in marine food webs (Cai et al., 2007; Ordiano-Flores et al., 2011; 2012). Mercury concentrations in tuna are known to vary geographically between ocean basins and species (Chouvelon et al., 2017; Houssard et al., 2019; Kojadinovic et al., 2006; Nicklisch et al., 2017), sometimes exceeding food safety guidelines (1 mg.kg-1 fresh tissue) (WHO and UNEP Chemicals, 2008). Mercury concentrations in organisms are 
governed by a complex interplay between physiological (age/length, metabolism and assimilation efficiencies), ecological (foraging depth and food web structures), biogeochemical (baseline in situ $\mathrm{MeHg}$ production and bioavailability) and physical (thermocline depth and sea surface temperature) processes (Cai et al., 2007; Chouvelon et al., 2017; Choy et al., 2009; Teffer et al., 2014). Recently, a spatial study from the western Pacific Ocean suggested that fish length and deeper thermoclines (used as a proxy of tuna foraging habitat) were the two main drivers enhancing $\mathrm{Hg}$ concentrations in tuna, with tuna trophic position (TP) and oceanic primary production being of less importance but still influencing tuna $\mathrm{Hg}$ concentrations (Houssard et al., 2019).

Despite their relatively high $\mathrm{MeHg}$ concentrations, tuna species are among the most popular fish species consumed worldwide (FAO, 2018). In the central and western Pacific Ocean, tuna fisheries accounted in 2017 for about $80 \%$ of the total Pacific Ocean catches and $54 \%$ of the global tuna catch (Williams and Reid, 2018). For Pacific Island countries and territories, the large tuna resources deliver great economic benefits through the sale of fishing access to distant water fishing nations and employment in fish processing (Bell et al., 2011; Gillett, 2009). In terms of food and nutrition security, tuna also represent a major source of proteins, essential fatty acids, vitamins and minerals (Di Bella et al., 2015; Sirot et al., 2012). These species have been consequently identified as key food resources for good nutrition to complement declining coastal resources in a context of high levels of diabetes and obesity in this region, while taking into account their $\mathrm{Hg}$ content (Bell et al., 2015).

Anticipating changes in human $\mathrm{Hg}$ exposure depends on our ability to capture and predict spatial and temporal $\mathrm{Hg}$ trends in marine food webs. Only two temporal studies of tuna $\mathrm{Hg}$ content are available to date, showing distinct results regarding $\mathrm{Hg}$ long-term trends. In the northern central Pacific Ocean (Hawaii), Drevnick et al. (2015) suggested that $\mathrm{Hg}$ concentrations in yellowfin tuna (Thunnus albacares) increased by at least 3.8\% per year between 1971 and 2008, despite considering only three sampling years. Conversely, in the North Atlantic Ocean, Lee et al. (2016) revealed a decadal decline of $\mathrm{Hg}$ concentrations in Atlantic bluefin tuna (T. thynnus) of about $2.4 \%$ between 2004 and 2012, 
suggesting potential benefits of the reduction of anthropogenic emission in North America. Unfortunately, no complementary trophic ecology data were available in those two studies to discuss if confounding ecological factors might contribute to the contrasted temporal trends of $\mathrm{Hg}$ content documented worldwide.

Stable isotope ratios of nitrogen $\left(\delta^{15} \mathrm{~N}\right)$ and carbon $\left(\delta^{13} \mathrm{C}\right)$ are widely used to examine trophic ecology of marine organisms (Fry, 2006). In particular, $\delta^{13} \mathrm{C}$ values provide information on basal organic carbon sources while $\delta^{15} \mathrm{~N}$ values are used to estimate the TP of a consumer as they increase predictably between prey and consumers. Therefore, $\delta^{15} \mathrm{~N}$ values are commonly used to explore $\mathrm{Hg}$ biomagnification along trophic webs (Atwell et al., 1998; Cai et al., 2007; Teffer et al., 2014). In addition to diet (i.e. trophic effects), variability of basal stable isotopic composition (i.e. baseline effects) also affects consumer $\delta^{15} \mathrm{~N}$ values (Lorrain et al., 2015b). Thus, $\delta^{15} \mathrm{~N}$ values also represent a potential proxy to infer baseline biological processes fuelling $\mathrm{Hg}$ methylation and/or net basal $\mathrm{MeHg}$ bioavailability. To account for complex primary production dynamics influencing the isotopic baseline, and produce accurate measures of a consumer's TP, amino acid compound-specific $\delta^{15} \mathrm{~N}$ analyses (AA-CSIA) are also used (Choy et al., 2015; Lorrain et al., 2015b). Within a consumer, the $\delta^{15} \mathrm{~N}$ values of source amino acids (Sr-AA; e.g., phenylalanine and glycine) track the $\delta^{15} \mathrm{~N}$ values at the base of the food web, while trophic AA (Tr-AA; e.g., glutamic acid), being enriched in ${ }^{15} \mathrm{~N}$ with each trophic level, provide information about a consumer's TP (Popp et al., 2007). Overall, the combination of muscle stable isotope ratios and AA-CSIA is a powerful tool to investigate both $\mathrm{Hg}$ methylation and biomagnification along food webs.

The specific objectives of our study were to i) investigate long-term trends of $\mathrm{Hg}$ concentrations in tuna from the New Caledonia-Fiji sub-region in the southwestern Pacific Ocean, and to ii) identify the main drivers of inter-annual variability of tuna $\mathrm{Hg}$ concentrations among physiological, ecological, biogeochemical and physical parameters. We analysed a unique long-term, continuous and large $\mathrm{Hg}$ dataset $(\mathrm{n}=590)$ in three commercial tropical tuna species (yellowfin, Thunnus albacares; bigeye, $T$. 
obesus; and skipjack, Katsuwonus pelamis) from 2001 to 2018. Complementary muscle $\delta^{15} \mathrm{~N}$ and $\delta^{13} \mathrm{C}$ values, AA-CSIA and model estimated phytoplankton $\delta^{15} \mathrm{~N}$ values were also used to explore the possible influence of biogeochemical and ecological factors on $\mathrm{Hg}$ content in tuna (i.e. changes in nutrient sources, primary productivity and tuna TP reflecting pathways of energy transfer). Finally, a suite of oceanographic variables (sea surface temperature, chlorophyll-a, net primary production, mixed layer depth, depths of isotherms $20^{\circ} \mathrm{C}$ and $12^{\circ} \mathrm{C}$ and oceanic El Niño index) were also included as potential explanatory factors of inter-annual variability in tuna $\mathrm{Hg}$ concentrations. 


\section{Materials and Methods}

\subsection{Study area}

Within the large oceanic region of the south western Pacific Ocean, the New Caledonia-Fiji sub-region is characterized by similar marine systems in terms of ocean dynamics, phytoplankton, zooplankton, and micronekton (Le Borgne et al., 2011). Oceanographic parameters are known to be driven by wind regimes, in particular southeast oriented trade winds and northwest oriented winds, associated with the monsoon season. During austral summers (from December to May), the trade winds become prevalent while the north-west oriented winds are more important during austral winters (from May to December) (Cravatte et al., 2015; Lorrain et al., 2015a). Compared to other regions in the Pacific Ocean where primary production mainly relies on $\mathrm{NO}_{3}^{-}$(with particulate organic matter $(\mathrm{POM}) \delta^{15} \mathrm{~N}$ values $\sim 4 \%$ ), our study area is known to be a hotspot of $\mathrm{N}_{2}$ fixation $\left(\mathrm{POM} \delta^{15} \mathrm{~N}\right.$ values $\sim 1 \%$ ), with diazotrophy showing some spatial and large seasonal variability (Bonnet et al., 2017; Garcia et al., 2007; Shiozaki et al., 2014). In the sub-region of New Caledonia-Fiji, a significant and unique effort of collecting and archiving tuna samples has been conducted since 2001 within the Pacific Marine Specimen Bank (https://www.spc.int/ofp/PacificSpecimenBank). Previous analyses of specimens from this tissue bank showed homogeneous $\mathrm{Hg}$ values in the New Caledonia and Fiji region (Houssard et al., 2019), which justifies the consideration of this sub-region to address temporal trends. Furthermore, Houssard et al. (2017) showed that tuna were relatively resident at this sub-regional scale as demonstrated by the similar isotope patterns between particulate organic matter and tuna in New Caledonia and Fiji. 


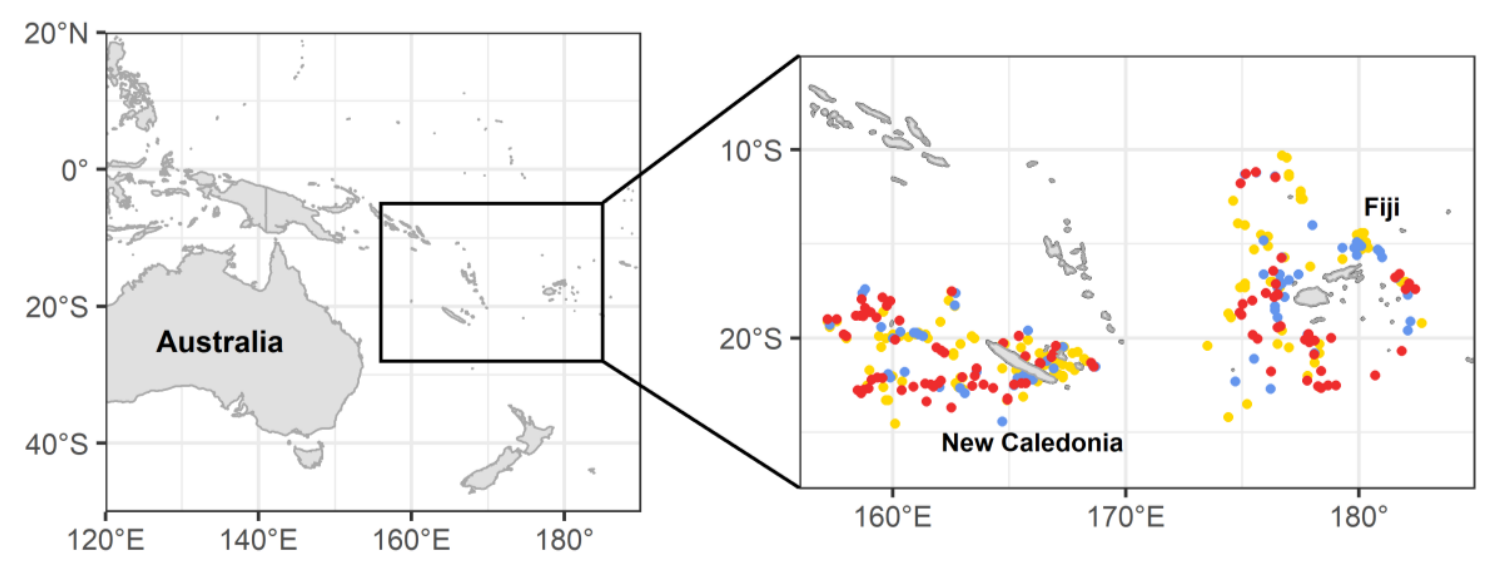

Figure 1: Sample location of bigeye (blue), yellowfin (yellow), and skipjack (red) caught around New Caledonia and Fiji.

\subsection{Sample and data collection}

2.2.1. Tuna sampling: Tuna samples were taken from the Pacific Marine Specimen Bank, corresponding to 326 yellowfin, 116 bigeye and 148 skipjack tuna, spanning the 2001-2018 time period $\left(\mathrm{n}_{\text {total }}=590\right)$ (Table S1). Sampling was performed onboard commercial fishing boats (longline) by trained scientific observers from the National Observer Programs of the Pacific Island Countries and Territories. Specimens were selected from $10^{\circ} \mathrm{S}$ to $25^{\circ} \mathrm{S}$ and from $157^{\circ} \mathrm{E}$ to $176^{\circ} \mathrm{W}$, covering the Economic Exclusive Zone (EEZ) of both New Caledonia and Fiji (Fig. 1). Fork length (FL) was measured to the lowest $\mathrm{cm}$ and ranged respectively for yellowfin, bigeye and skipjack from 60 to 160 $\mathrm{cm}(121 \pm 18 \mathrm{~cm}$; mean \pm SD), 64 to $160 \mathrm{~cm}(108 \pm 21 \mathrm{~cm}$; mean $\pm \mathrm{SD})$ and 42 to $90 \mathrm{~cm}(72 \pm 7 \mathrm{~cm}$; mean $\pm \mathrm{SD}$ ). For each fish, a white muscle sample was collected from the anal area and stored frozen at $-20^{\circ} \mathrm{C}$ prior to analyses.

2.2.2. Environmental variables: Seven oceanographic variables shown to influence variability of $\mathrm{Hg}$ concentrations in tropical tuna (Houssard et al., 2019) were used in this study to explore the physical drivers of $\mathrm{Hg}$ concentrations at the surface and at depth. Surface variables included monthly mean sea 
surface temperature $\left(\mathrm{SST}\right.$ in ${ }^{\circ} \mathrm{C}$ ) from the National Oceanic and Atmospheric Administration (NOAA, https://www.ncdc.noaa.gov/oisst; (Reynolds et al., 2002) and monthly chlorophyll-a observations $\left(\mathrm{Chl}-\mathrm{a}, \mathrm{mg} \cdot \mathrm{m}^{-3}\right)$ from a continuous dataset of merged L4 Ocean Colour products provided by GlobColour (http://globcolour.info). Monthly means of net primary production (NPP, mg C.m ${ }^{-2}$.day 1) were derived from a vertically generalized production model (VGPM, http://www.science.oregonstate.edu/ocean.productivity/custom.php; Behrenfeld and Falkowski, 1997). Variables at depth or sub-surface included the mixed layer depth (MLD) and depths of the $12^{\circ} \mathrm{C}$ and $20^{\circ} \mathrm{C}$ isotherms $\left(\mathrm{D}_{\text {iso12 }}\right.$ and $\left.\mathrm{D}_{\mathrm{iso} 20}, \mathrm{~m}\right)$, all obtained from the monthly global ARMOR3D L4 dataset (Guinehut et al., 2012). The Oceanic Niño Index (ONI), used to monitor the El Niño-Southern Oscillation (ENSO), was also collected over the study period. Except for this last variable, all monthly data were extracted on a $1^{\circ}$ x $1^{\circ}$ grid from 2001 to 2018 . Assuming the relative oceanic homogeneity of the New Caledonia-Fiji region (Houssard et al., 2017; Le Borgne et al., 2011), physical variables were averaged over the entire study area to examine only temporal relationships between tuna $\mathrm{Hg}$ concentrations and the environment. Furthermore, given the long process of $\mathrm{MeHg}$ bioaccumulation in tuna muscle (Kwon et al., 2016), we assumed that $\mathrm{Hg}$ values of a given individual captured at a single date and place is not exclusively explained by the environmental conditions at this date, but also by the conditions prevailing during the previous months or years. As ${ }^{15} \mathrm{~N}$ turnover ( $\sim$ six months) in tuna white muscle is known to be shorter than MeHg turnover (Madigan et al., 2012), all oceanographic variables were averaged over a six-month period preceding individual capture date to explain both $\mathrm{Hg}$ and nitrogen isotope data.

2.2.3. Estimates of baseline phytoplankton $\delta^{15} \mathbf{N}$ values: To explore the potential relationship between the nitrogen cycle and change in tuna $\mathrm{Hg}$ concentrations at the top of the food web, baseline phytoplankton $\delta^{15} \mathrm{~N}$ values were estimated from a model of ocean biogeochemistry and isotopes (MOBI, Somes et al., 2017) at each tuna sample location and year from a hindcast simulation. The 
biogeochemical component is a 2N2PZD (2 Nutrients, 2 Phytoplankton, 1 Zooplankton, and 1 Detritus) ecosystem model (Somes and Oschlies, 2015). The processes in the model that fractionate the nitrogen isotopes (i.e. preferentially incorporate ${ }^{14} \mathrm{~N}$ into the product) are phytoplankton $\mathrm{NO}_{3}$ assimilation (6 \%o), zooplankton excretion (4 \%), $\mathrm{N}_{2}$ fixation (1\%o), water column denitrification (20 $\%$ ) and benthic denitrification (6\%o), in which the respective fractionation factor yields the $\delta^{15} \mathrm{~N}$ difference between substrate and product (Somes et al., 2010). The baseline $\delta^{15} \mathrm{~N}$ values reproduce the major features in a global seafloor $\delta^{15} \mathrm{~N}$ database (Tesdal et al., 2013).

\subsection{Analytical methods}

2.3.1. Total mercury concentration analysis: Total $\mathrm{Hg}$ concentrations were analysed on 590 samples: 326 yellowfin, 116 bigeye and 148 skipjack. The majority $(n=458)$ of total $\mathrm{Hg}$ concentrations were performed on homogenized freeze-dried samples by thermal decomposition, gold amalgamation and atomic adsorption detection (DMA-80, Milestone, Italy) at GET (Toulouse, France). Blanks and two biological standard reference materials, TORT-3 (lobster hepatopancreas; Hg $=292 \pm 22$ ng.g ${ }^{-1}$ $\mathrm{dw}$ ) and IAEA-436 (tuna fish flesh homogenate; $\mathrm{Hg}=4190 \pm 360 \mathrm{ng} \cdot \mathrm{g}^{-1} \mathrm{dw}$ ), covering a wide range of $\mathrm{Hg}$ concentrations, were routinely used in each analytical batch to check $\mathrm{Hg}$ measurement accuracy. Complementary Hg data ( $\mathrm{n}=132$, only skipjack tuna) were analysed at the IRD laboratory in Noumea (New Caledonia) by hot plate acidic digestion $\left(\mathrm{HNO}_{3}-\mathrm{H}_{2} \mathrm{O}_{2}\right)$ followed by Cold Vapor Atomic Fluorescence Spectroscopy. Blanks and one biological standard reference materials, DOMR-4 (fish protein; $\mathrm{Hg}=412 \pm 36 \mathrm{ng} \cdot \mathrm{g}^{-1} \mathrm{dw}$ ) were routinely used in each analytical batch to check $\mathrm{Hg}$ measurement accuracy and traceability. Hg contents are expressed on a dry weight basis (dw).

2.3.2. Bulk muscle and compound-specific stable isotope analysis: Muscle stable isotope ratios were measured on the 590 samples analysed in $\mathrm{Hg}$ but also on complementary samples available from 
our study area $(\mathrm{n}=85)$ but in too limited quantities to perform both $\mathrm{Hg}$ and stable isotope analyses. In total, 675 samples were therefore analysed for stable isotopes: 360 yellowfin, 150 bigeye and 165 skipjack. $\delta^{15} \mathrm{~N}$ and $\delta^{13} \mathrm{C}$ values were obtained from $\sim 1 \mathrm{mg}$ homogenized freeze-dried samples packed in tin cups and were analyzed using a Costech elemental analyser coupled to an isotope ratio mass spectrometer (Thermo Scientific Delta Advantage with a Conflo IV interface) at Union College (New York, USA). Reference standards (EA Consumables sorghum flour $\left(\delta^{13} \mathrm{C}=-13.78 \pm 0.17, \delta^{15} \mathrm{~N}=1.58\right.$ $\pm 0.15)$, in house acetanilide $\left(\delta^{13} \mathrm{C}=-34.07, \delta^{15} \mathrm{~N}=-0.96\right)$, IAEA- $\mathrm{N}-2$ ammonium sulfate $\left(\delta^{15} \mathrm{~N}=20.3\right.$ $\pm 0.2)$, and IAEA-600 caffeine $\left.\left(\delta^{13} \mathrm{C}=-27.771 \pm 0.043, \delta^{15} \mathrm{~N}=1.0 \pm 0.2\right)\right)$ were used for isotopic corrections, and to assign the data to the appropriate isotopic scale with analytical precision better than 0.1\%. Percent $\mathrm{C}$ and $\mathrm{N}$ were calculated using additional acetanilide standards of varying mass. Corrections were done using a regression method. Results were reported in the $\delta$ unit notation and expressed as parts per thousand (\%) relative to international standards (atmospheric $\mathrm{N}_{2}$ for nitrogen and Vienna Pee Dee belemnite (VPDB) for carbon). Reproducibility of several samples measured in triplicate was $<0.2 \%$. For samples with elevated lipid content $(\mathrm{C}: \mathrm{N}>3.5), \delta^{13} \mathrm{C}$ values were corrected using a mass balance equation with parameters derived from Atlantic bluefin tuna muscle (Logan et al., 2008).

For AA-CSIA, we used both published (Houssard et al., 2017) and newly-analysed amino acid compound-specific $\delta^{15} \mathrm{~N}$ data on yellowfin tuna $(\mathrm{n}=10)$ which had the most robust time series among the three tuna species on individuals collected in 2003, 2007, 2010, 2013, 2016 and $2018(n=16)$. To do so, the freeze-dried samples were prepared by acid hydrolysis followed by esterification and trifluoroacetylation as per Dale et al. (2011). The $\delta^{15} \mathrm{~N}$ isotope values of individual amino acids were determined with a Trace GC gas chromatograph interfaced with a Delta V Plus isotope ratio mass spectrometer (IRMS) through a GC-C combustion furnace $\left(980^{\circ} \mathrm{C}\right)$, reduction furnace $\left(650^{\circ} \mathrm{C}\right)$ and liquid $\mathrm{N}_{2}$ cold trap. The samples $(0.5 \mu \mathrm{l})$ were injected splitless onto a forte BPX5 capillary column $\left(30 \mathrm{~m} \times 0.32 \mathrm{~mm} \times 1.0 \mu \mathrm{m}\right.$ film thickness) at an injector temperature of $180^{\circ} \mathrm{C}$ with a constant helium 
flow rate of $1.5 \mathrm{ml} \mathrm{min}{ }^{-1}$. The column was initially held at $50^{\circ} \mathrm{C}$ for $2 \mathrm{~min}$ and then increased to $120^{\circ} \mathrm{C}$ at a rate of $10^{\circ} \mathrm{C} \cdot \mathrm{min}^{-1}$. Once at $120^{\circ} \mathrm{C}$, the temperature was increased at a rate of $4^{\circ} \mathrm{C} \cdot \mathrm{min}^{-1}$ to $195^{\circ} \mathrm{C}$ and then at $5^{\circ} \mathrm{C} \cdot \mathrm{min}^{-1}$ to $235^{\circ} \mathrm{C}$ where it was held for $5 \mathrm{~min}$. The temperature was then further increased to $300^{\circ} \mathrm{C}$ at $15^{\circ} \mathrm{C} \cdot \mathrm{min}^{-1}$ and held for $8 \mathrm{~min}$. All samples were analysed at least in triplicate. The $\delta^{15} \mathrm{~N}$ values were normalised as follows: each sample analysis consisted of three separate IRMS analyses bracketed by a suite of amino acids with known $\delta^{15} \mathrm{~N}$ values. The slope and intercept of known versus measured values were then used to correct the measured values for the sample set. Reproducibility associated with isotopic analysis of glutamic acid and phenylalanine averaged $\pm 0.44 \%$ ( 1 SD) and ranged from $\pm 0.06 \%$ to $\pm 0.85 \%$ respectively.

2.3.3. Trophic position estimates: Tuna TP was estimated using the difference of $\delta^{15} \mathrm{~N}$ values in trophic (Tr-AA) and source (Sr-AA) amino acids, obtained by the following equation:

$$
\mathrm{TP}_{\mathrm{Tr}-\mathrm{Sr}}=\frac{\delta^{15} \mathrm{~N}_{\mathrm{Tr}-\mathrm{AA}}-\delta^{15} \mathrm{~N}_{\mathrm{Sr}-\mathrm{AA}}+\beta_{\mathrm{Tr}-\mathrm{Sr}}}{\mathrm{TEF}_{\mathrm{Tr}-\mathrm{Sr}}}+1
$$

where $\delta^{15} \mathrm{~N}_{\mathrm{Sr}-\mathrm{AA}}$ is the weighted average of glycine and phenylalanine $\delta^{15} \mathrm{~N}_{\mathrm{AA}}$ values and $\delta^{15} \mathrm{~N}_{\mathrm{Tr}-\mathrm{AA}}$ the weighted average of alanine, glutamic acid, leucine and proline $\delta^{15} \mathrm{~N}_{\mathrm{AA}}$ values. $\beta_{\mathrm{Tr}-\mathrm{Sr}}$ is the difference between $\mathrm{Tr}-\mathrm{AA}$ and $\mathrm{Sr}-\mathrm{AA}$ in primary producers and $\mathrm{TEF}_{\mathrm{Tr}-\mathrm{Sr}}$ is the ${ }^{15} \mathrm{~N}$ enrichment between Tr-AA and Sr-AA per TP. $\beta_{\mathrm{Tr}-\mathrm{Sr}}$ and $\mathrm{TEF}_{\mathrm{Tr}-\mathrm{Sr}}$ were set respectively at 3.6 and 5.7 (Bradley et al., 2015). Using the weighted average of Sr-AA and Tr-AA reduced uncertainty due to the possible large variations of $\delta^{15} \mathrm{~N}_{\mathrm{AA}}$ values (Hayes et al., 1990). Uncertainty in TP estimates was calculated by propagation of errors according to Bradley et al. (2015) with a mean error of 0.4. 


\subsection{Statistical analysis}

Distribution differences of $\mathrm{Hg}$ concentrations, muscle $\delta^{15} \mathrm{~N}$ and $\delta^{13} \mathrm{C}$ values between species were first tested with a Kruskal-Wallis test followed by Dunn's post hoc test as hypothesis of normality was not met.

2.4.1. Transformation of mercury concentrations: Tuna $\mathrm{Hg}$ concentrations were log-transformed to guarantee the homogeneity of variance (Zuur et al., 2010). Further, as Hg is known to bioaccumulate with length (and age), a power-law relationship $\left(\log (\mathrm{Hg})=\mathrm{a} \times(\mathrm{FL}-\mathrm{b})^{\mathrm{C}}-\mathrm{d}\right)$ was fit between $\log (\mathrm{Hg})$ and fish length (fork length, FL) to characterize the bioaccumulative processes in each tuna species and remove this length effect in further analysis. This allowed the influence of other potential factors governing $\mathrm{Hg}$ concentrations in tuna to be investigated. Residuals from the length-based $\mathrm{Hg}$ model (i.e. observed values - predicted values) were extracted and used to calculate lengthstandardized $\mathrm{Hg}$ concentrations (at mean species lengths, i.e. FL=100 cm for yellowfin and bigeye and at $\mathrm{FL}=70 \mathrm{~cm}$ for skipjack), thereafter defined as "standardized $\mathrm{Hg}$ concentrations".

2.4.2. Temporal trend and structure analysis: Temporal patterns of $\mathrm{Hg}$ concentrations in tuna were examined with Moran's eigenvectors maps (MEM) which are derived from a spectral decomposition of the temporal relationships among the sampling dates (Dray et al., 2006). This decomposition generates orthogonal eigenfunctions that can then be used in statistical models as explanatory variables representing the temporal pattern observed. Species-specific temporal eigenfunction analyses were conducted on $\log (\mathrm{Hg})$ and standardized $\mathrm{Hg}$ concentrations separately following the method of Legendre and Gauthier (2014). To account for the seasonality in our study region, each variable was aggregated by year and season, resulting in 36 season/year couples (i.e. austral winter and austral summer per year from 2001 to 2018). Briefly, long-term trends of $\mathrm{Hg}$ concentrations were first tested 
on seasonal means of $\mathrm{Hg}$ concentrations with a redundancy analysis (RDA) followed by an ANOVA like permutation test. Secondly, to investigate the temporal structure of $\log (\mathrm{Hg})$ and standardized $\mathrm{Hg}$ concentrations, we built distance-based matrices among the sampling periods and distance-based MEMs (dbMEM) eigenfunctions. As sampling design was not regular for the three tuna species, dbMEMs were built over the 36 seasons, then the seasons with no sample for a species were removed as recommended with irregularly designed sampling surveys (Brind'Amour et al., 2018). dbMEMs modeling positive (i.e. observations that are closer in time tend to display values that are more similar than observations paired at random) or negative temporal correlation between seasons were selected and tested with redundancy analysis (RDA) followed by ANOVA like permutation tests to reveal any temporal structure in the response variables. Temporal structure of $\mathrm{Hg}$ concentrations was investigated only for yellowfin and skipjack as there was not enough data per season for bigeye.

For potential ecological and environmental drivers of $\mathrm{Hg}$ concentrations, only long-term trends were investigated as no particular seasonal structure was revealed for both $\log (\mathrm{Hg})$ and standardized $\mathrm{Hg}$ concentrations. RDA followed by ANOVA like permutation tests were then fitted separately on tuna muscle $\delta^{15} \mathrm{~N}$ and $\delta^{13} \mathrm{C}$ values, and on each environmental variable (SST, MLD, Chl-a, NPP, Diso12 and

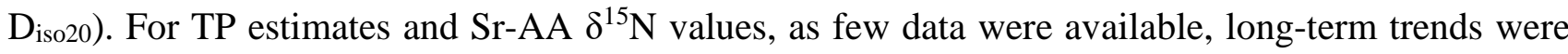
investigated using a linear regression fitted along years.

\subsubsection{Effects of physical and ecological drivers on the temporal variability of $\mathrm{Hg}$ content:}

Generalized additive models (GAM) were used to test the effects of potential predictors on temporal variations of $\mathrm{Hg}$ concentrations following the formulae:

$$
\mathrm{Y}=\alpha+\mathrm{s}_{1}\left(\mathrm{X}_{1}\right)+\mathrm{s}_{2}\left(\mathrm{X}_{2}\right)+\ldots+\mathrm{s}_{\mathrm{n}}\left(\mathrm{X}_{\mathrm{n}}\right)+\varepsilon
$$

where $\mathrm{Y}$ is the expected value of the response variable (i.e. $\log (\mathrm{Hg})$ or standardized $\mathrm{Hg}$ concentrations), $\alpha$ is the model intercept, $s_{i}\left(X_{i}\right)$ is a thin-plate-spline smooth function of the explanatory variable $i$, and 
$\varepsilon$ is the error term. Standardized $\mathrm{Hg}$ concentrations were assumed to follow a Gamma distribution while $\log (\mathrm{Hg})$ a Gaussian one. Explanatory variables tested included surface (SST, Chl-a, NPP and ONI) and deep ( $\mathrm{D}_{\text {iso12, }} \mathrm{D}_{\text {iso20 }}$ and MLD) oceanographic variables as well as ecological $\left(\delta^{15} \mathrm{~N}\right.$ and $\delta^{13} \mathrm{C}$ values) factors. Fish length was also added in the models testing $\log (\mathrm{Hg})$. Before performing model computation, variance inflation factors (VIF) were calculated between all explanatory variables to detect collinearity. Covariates with the highest VIF were subsequently removed until the highest VIF value was $<5$ (Zuur et al., 2010). With this method, MLD and Chl-a were found to be collinear to other variables and were then removed from the explanatory variables. $D_{\text {isol2 }}$ and $D_{\text {iso20 }}$ were highly correlated, so only separate models using either $\mathrm{D}_{\text {iso12 }}$ or $\mathrm{D}_{\text {iso20 }}$ were tested. Explanatory variables were fitted in the GAM with a low spline complexity $(\mathrm{k}=3)$ to reduce over-fitting. A backward selection approach was used and we chose the model with the lowest Akaike's Information Criterion corrected for small samples sizes (AICc, Burnham and Anderson, 2004). Finally, for each best-fit GAM, assumptions of residuals temporal trend and auto-correlation were examined graphically with diagnostic plots. The deviance explained (\% DE) for each model was compared to assess predictive capacity. To determine the amount of variation explained by each explanatory variable, we fitted a separate model for individual variable. GAM were fitted in $\mathrm{R}$ using the mgcv package (Wood and Wood, 2015).

\subsubsection{Effects of baseline processes on tuna $\mathrm{Hg}$ concentrations and tuna $\delta^{15} \mathrm{~N}$ values: To investigate} the potential influence of baseline processes, in particular the effect of different nitrogen sources $\left(\mathrm{NO}_{3}^{-}, \mathrm{NO}_{2}\right)$ fuelling primary productivity in this region (Bonnet et al., 2017; Garcia et al., 2007; Shiozaki et al., 2014), we fitted linear regressions between MOBI estimates of phytoplankton $\delta^{15} \mathrm{~N}$ values and both standardized $\mathrm{Hg}$ concentrations and muscle $\delta^{15} \mathrm{~N}$ values in the three tuna species. Complementary linear regressions were fitted on yellowfin samples analysed in $\delta^{15} \mathrm{~N}$ AA-CSIA to compare standardized $\mathrm{Hg}$ concentrations, tuna muscle $\delta^{15} \mathrm{~N}$ values and phytoplankton $\delta^{15} \mathrm{~N}$ estimates 
regarding $\mathrm{Sr}-\mathrm{AA} \delta^{15} \mathrm{~N}$ values, used as proxies of baseline nitrogen isotope values. All statistical analyses were performed with R 3.6.1 (R Core Team, 2018). 


\section{Results}

\subsection{Patterns and temporal variability of mercury concentrations}

Mercury concentrations (mean $\pm \mathrm{SD}$, min-max, dw) differed according to species (Kruskal-Wallis, $p<0.001)$ with significantly higher levels in bigeye $\left(2.7 \pm 1.7 \mu \mathrm{g} . \mathrm{g}^{-1}, 0.3-8.6 \mu \mathrm{g} . \mathrm{g}^{-1}\right.$; Dunn's test, $p<0.001)$ than in yellowfin $\left(0.7 \pm 0.5 \mu \mathrm{g} . \mathrm{g}^{-1}, 0.1-5.1 \mu \mathrm{g} . \mathrm{g}^{-1}\right)$ and in skipjack $\left(0.7 \pm 0.3 \mu \mathrm{g} \cdot \mathrm{g}^{-1}, 0.2-1.7\right.$

$\left.\mu \mathrm{g} . \mathrm{g}^{-1}\right)$ (Figs. 2a \& S1). Fish length and $\log (\mathrm{Hg})$ were positively correlated and fish length explained respectively $45 \%, 39 \%$ and $18 \%$ of the muscle $\mathrm{Hg}$ variations in bigeye, yellowfin and skipjack. Coefficients (a, b, c and d) of the power-law relationships are specified per species in Figure 2c.

Inter-annual variability from 2001 to 2018 was detected in both log-transformed and standardized $\mathrm{Hg}$ concentrations for each tuna species, yet no significant long-term temporal trends were detected (Figs. 2a \& 2d; Table 1). Furthermore, models based upon the MEM were not significant for any variable and any tuna species (Table 1). This illustrates the lack of any significant seasonal structure of $\log (\mathrm{Hg})$ and standardized Hg concentrations between 2001 and 2018 in the south western Pacific Ocean.

\subsection{Temporal variability of tuna isotopic ratios and trophic position}

Muscle $\delta^{15} \mathrm{~N}$ values varied between the three tuna species (Kruskal-Wallis, $p<0.001$; Dunn's test, $p<0.001$ between all pairs of species). Highest $\delta^{15} \mathrm{~N}$ values were found in bigeye $(12.6 \pm 1.6 \%$, intermediate values in yellowfin $(10.8 \pm 1.8 \%$ ) and lowest values in skipjack $(9.9 \pm 1.4 \%$ o) (Figs. 2e $\&$ S1). For the three species, inter-annual variability between 2001 and 2018 was detected on muscle $\delta^{15} \mathrm{~N}$ values but no increasing or decreasing long-term trends were found (Fig. 2e; Table 1).

Similarly, $\delta^{13} \mathrm{C}$ values differed between species (Kruskal-Wallis, $p<0.001$; Dunn's test, $p<0.01$ between all pairs of species) with highest values in bigeye $(-16.2 \pm 1.0 \%$ ), intermediate values in yellowfin $(-16.4 \pm 1.0 \%$ ) and lowest values in skipjack $(-16.8 \pm 1.1 \%$ ) (Figs $2 \mathrm{f} \& \mathrm{~S} 1)$. Contrary to 
muscle $\delta^{15} \mathrm{~N}$ values, $\delta^{13} \mathrm{C}$ values were found to decrease significantly between 2001 and 2018 by a mean annual rate of $0.08 \%$ for bigeye and skipjack and of $0.07 \%$ for yellowfin (Fig. 2f; Table 1).

TP estimates and $\mathrm{Sr}-\mathrm{AA} \delta^{15} \mathrm{~N}$ values in yellowfin varied respectively from 3.4 to $5.5(4.5 \pm 0.5)$ and 5.1 to $11.7 \%$ ( $0.4 \pm 3.9)$ (Fig. 3). Like muscle $\delta^{15} \mathrm{~N}$ values, they varied inter-annually between 2003 and 2018, however they showed no significant long-term trend $(p>0.05)$.

Table 1: ANOVA like permutation results to test temporal trend and structure of $\log (\mathrm{Hg})$, standardized $\mathrm{Hg}$ concentrations, muscle $\delta^{15} \mathrm{~N}$ values and $\delta^{13} \mathrm{C}$ values of tropical tuna. FL: fork length; n: number of tuna individuals; $F$ and $p$-value: statistics of the tests. * indicates significant temporal trend.

\begin{tabular}{|c|c|c|c|c|c|c|c|c|c|}
\hline \multirow[t]{2}{*}{ Species } & \multirow{2}{*}{$\begin{array}{l}\text { Response } \\
\text { variable }\end{array}$} & \multirow{2}{*}{$\begin{array}{l}\text { FL (cm) } \\
\text { min-max }\end{array}$} & \multirow[t]{2}{*}{$\mathrm{n}$} & \multicolumn{2}{|c|}{ Temporal trend } & \multicolumn{2}{|c|}{$\begin{array}{c}\text { MEM modelling } \\
\text { positive correlation }\end{array}$} & \multicolumn{2}{|c|}{$\begin{array}{c}\text { MEM modelling } \\
\text { negative correlation }\end{array}$} \\
\hline & & & & $F$ & $p$-value & $F$ & $p$-value & $F$ & $p$-value \\
\hline \multirow{4}{*}{ bigeye } & $\log (\mathrm{Hg})$ & & 116 & 0.088 & 0.800 & \multicolumn{4}{|c|}{ Not enough data } \\
\hline & standardized $\mathrm{Hg}$ & $64-160$ & 116 & 0.055 & 0.799 & \multicolumn{4}{|c|}{ Not enough data } \\
\hline & $\delta^{15} \mathrm{~N}$ & & 163 & 0.132 & 0.254 & \multicolumn{4}{|c|}{ Not tested } \\
\hline & $\delta^{13} \mathrm{C}$ & & 163 & 4.043 & $0.044 *$ & \multicolumn{4}{|c|}{ Not tested } \\
\hline \multirow{4}{*}{ yellowfin } & $\log (\mathrm{Hg})$ & & 326 & 4.340 & 0.056 & 0.678 & 0.760 & 2.495 & 0.131 \\
\hline & standardized $\mathrm{Hg}$ & $60-160$ & 326 & 0.026 & 0.888 & 0.4903 & 0.887 & 2.15 & 0.202 \\
\hline & $\delta^{15} \mathrm{~N}$ & & 386 & 0.019 & 0.580 & \multicolumn{4}{|c|}{ Not tested } \\
\hline & $\delta^{13} \mathrm{C}$ & & 386 & 10.651 & $0.005 *$ & \multicolumn{4}{|c|}{ Not tested } \\
\hline \multirow{4}{*}{ skipjack } & $\log (\mathrm{Hg})$ & & 148 & 1.470 & 0.247 & 666.170 & 0.053 & Not e & gh data \\
\hline & standardized $\mathrm{Hg}$ & $42-90$ & 148 & 2.248 & 0.169 & 54.523 & 0.127 & Not e & gh data \\
\hline & $\delta^{15} \mathrm{~N}$ & & 165 & 1.186 & 0.308 & \multicolumn{4}{|c|}{ Not tested } \\
\hline & $\delta^{13} \mathrm{C}$ & & 165 & 4.321 & $0.041 *$ & \multicolumn{4}{|c|}{ Not tested } \\
\hline
\end{tabular}


(a)

bigeye

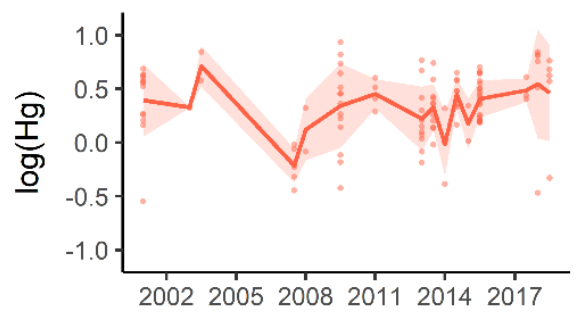

(b)

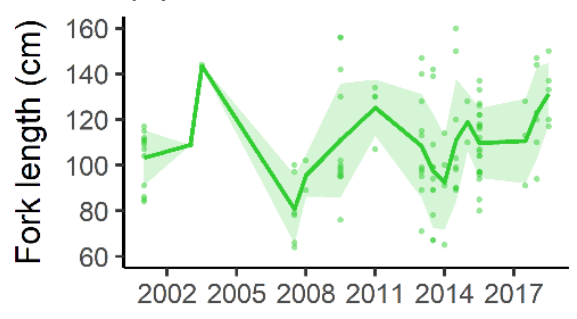

(c)

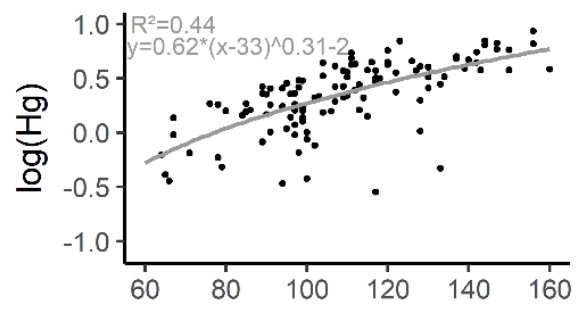

3ิ

(d)

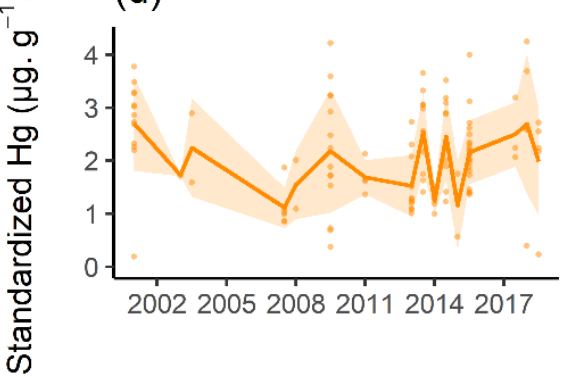

(e)

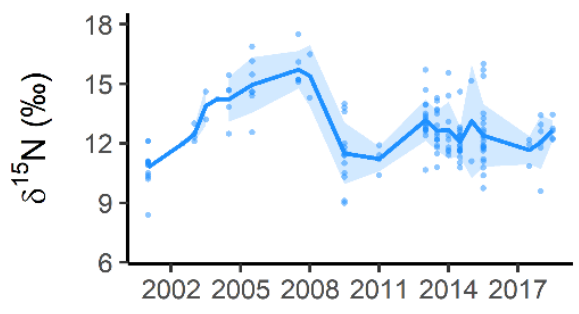

(f)

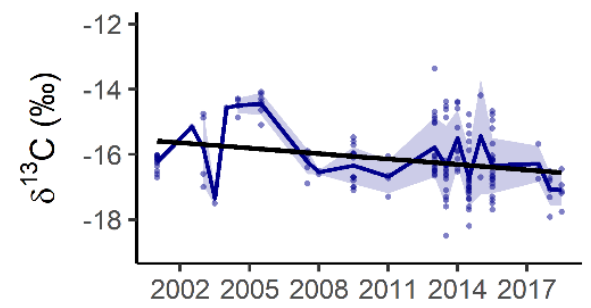

yellowfin
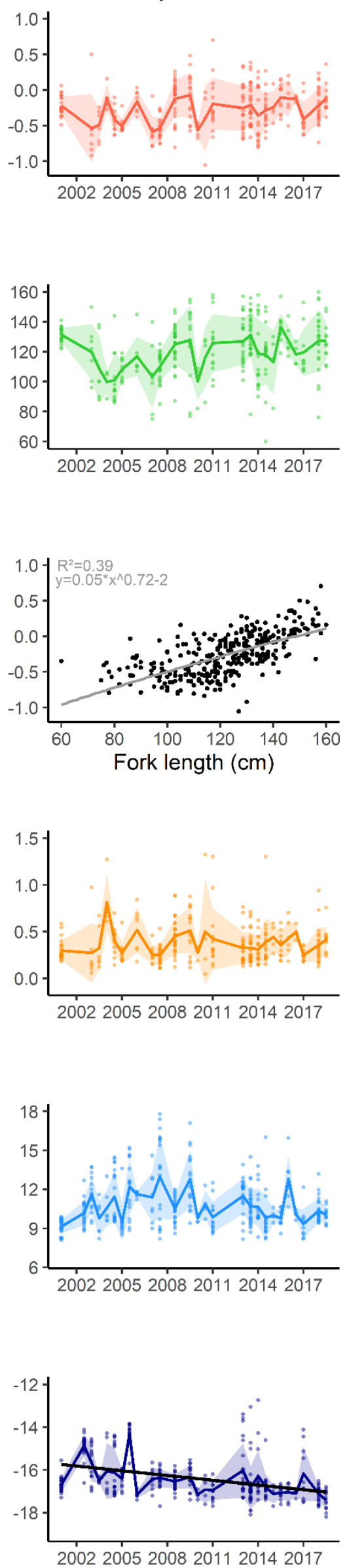

skipjack
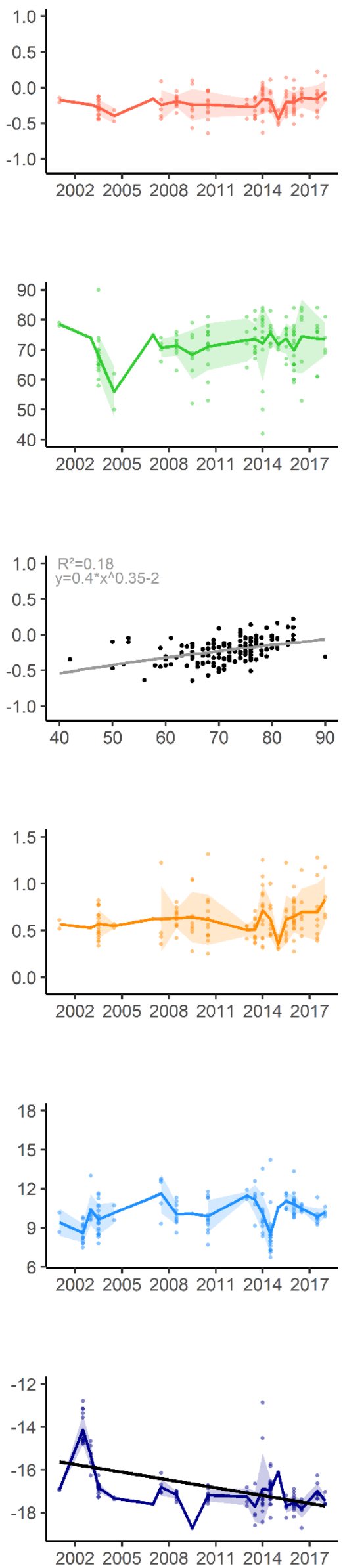
Figure 2: Time series of a) $\log (\mathrm{Hg}), \mathrm{b})$ tuna fork length $(\mathrm{cm}), \mathrm{d})$ standardized $\mathrm{Hg}$ concentrations $\left.\left(\mu \mathrm{g} \cdot \mathrm{g}^{-1}, \mathrm{dw}\right), \mathrm{e}\right)$ tuna muscle $\delta^{15} \mathrm{~N}$ values (\%) and f) tuna muscle $\delta^{13} \mathrm{C}$ values (\%o) (the black lines represent the significant temporal trends). c) power-law relationships between $\log (\mathrm{Hg})$ and fork length;. The coloured lines and shadows give respectively the seasonal means and standard deviations. The dots are the observation values.

(a)

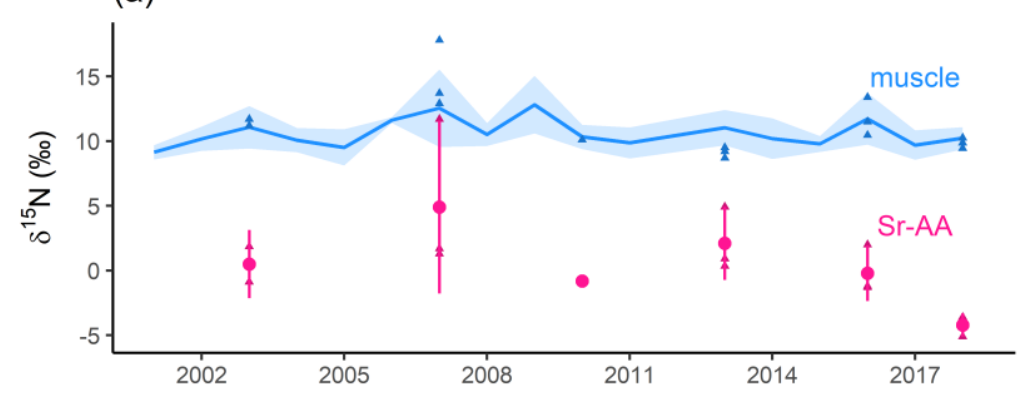

(b)

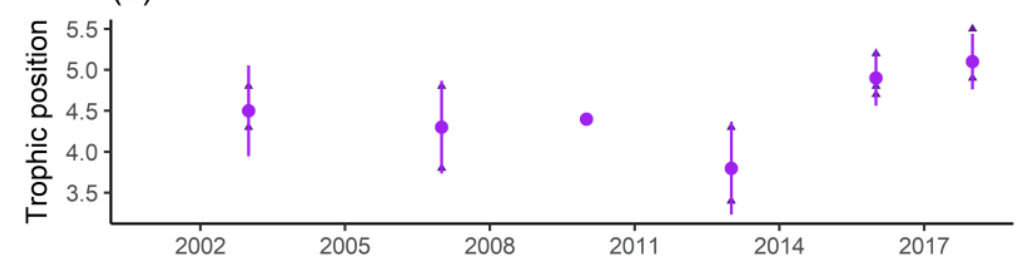

Figure 3: a) Time series of muscle $\delta^{15} \mathrm{~N}$ values (blue), source amino acid (Sr-AA) $\delta^{15} \mathrm{~N}$ values (pink) (\%o) and b) trophic position (TP) estimates (purple) in yellowfin. The blue line and the blue shadow give respectively the annual means and standard deviation of muscle $\delta^{15} \mathrm{~N}$ values. The dots and lines represent respectively the mean values and the standard deviations of Sr-AA $\delta^{15} \mathrm{~N}$ values and TP estimates. The triangles are the observations for the selected yellowfin samples analysed for AA-CSIA.

\subsection{Seasonal variability and trend of the environmental variables}

Over the six environmental variables considered, only the depth of the isotherm $20^{\circ} \mathrm{C}\left(\mathrm{D}_{\text {iso20 }}\right)$ was found to increase significantly over the two last decades (Fig. 4; Table S2, $p<0.05$ ). The five other variables (SST, Chl-a, MLD, NPP and $\mathrm{D}_{\text {iso12) }}$ remained stable between 2001 and 2018 (all $p>0.05$ ). All physical variables showed strong seasonality over our study period. 
(a)

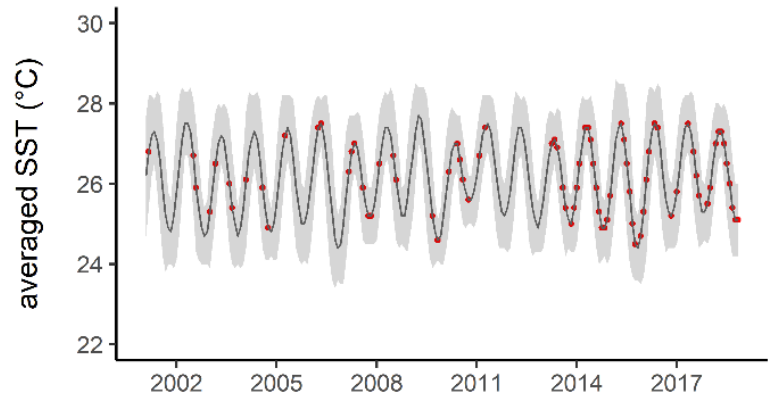

(c)

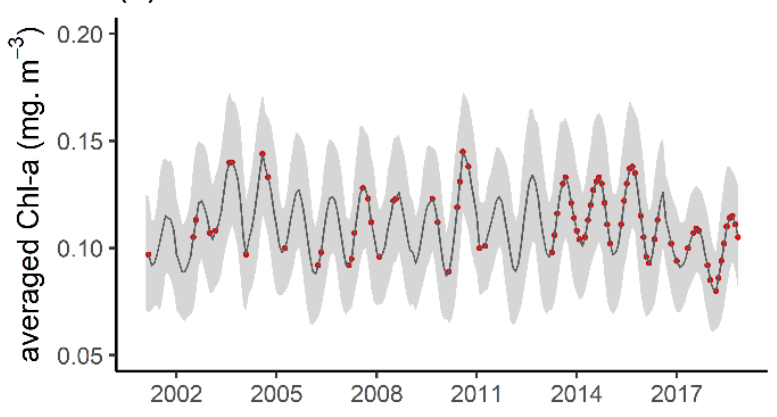

(e)

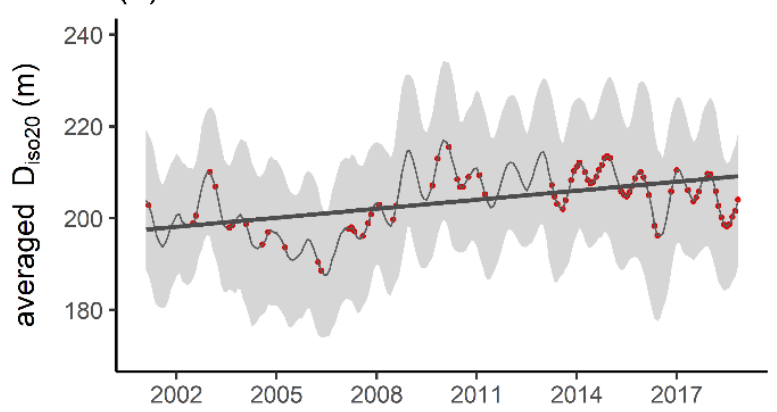

(g)

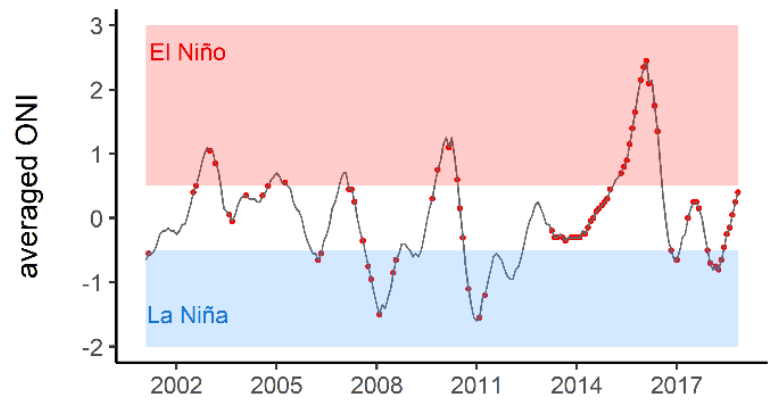

(b)

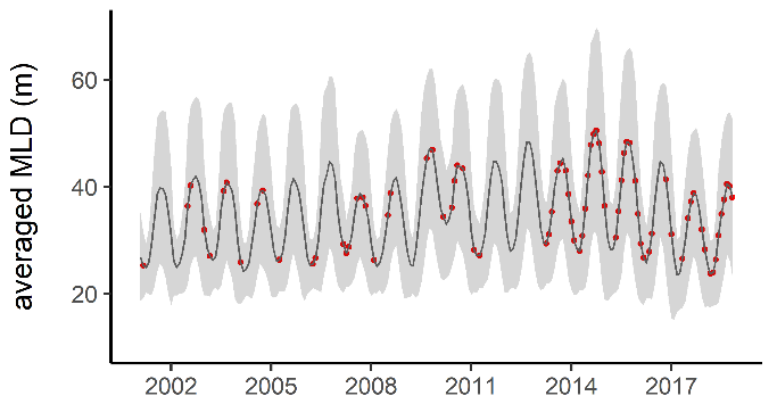

(d)

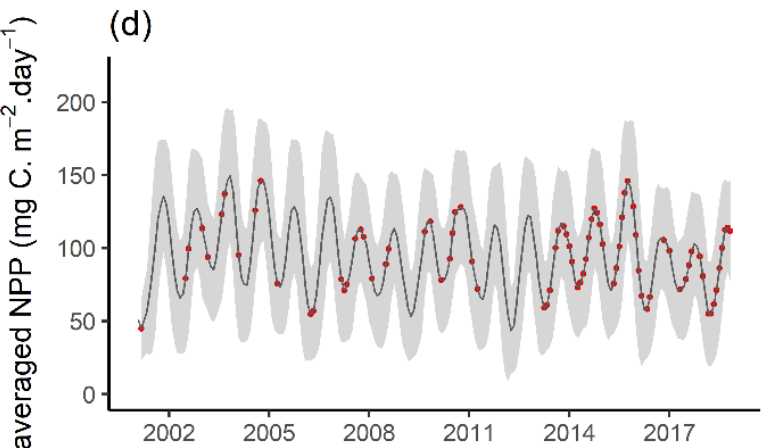

(f)

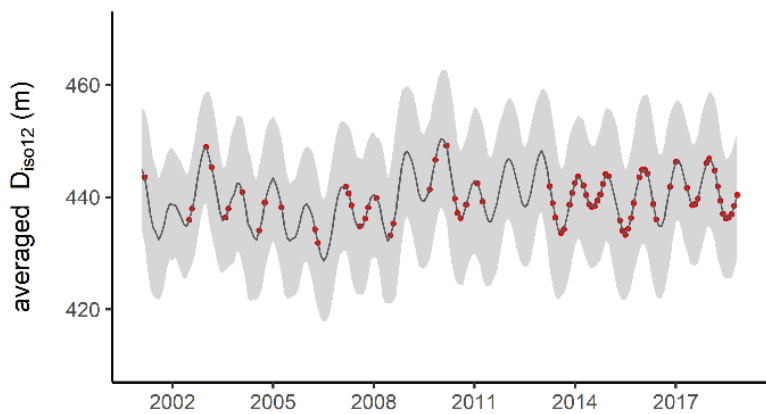

Figure 4: Seasonal variations of 6-month averages of oceanic variables in the New Caledonia-Fiji region. a) sea surface temperature $\left.\left({ }^{\circ} \mathrm{C}\right), \mathrm{b}\right)$ mixed layer depth $\left.(\mathrm{m}), \mathrm{c}\right) \mathrm{Chl}-\mathrm{a}\left(\mathrm{mg} \cdot \mathrm{m}^{-3}\right)$, d) net primary production $\left(\mathrm{mg} \mathrm{C} \cdot \mathrm{m}^{-2} \cdot\right.$ day $\left.^{-1}\right)$, e) depth of isotherm $20^{\circ} \mathrm{C}(\mathrm{m}), \mathrm{f}$ ) depth of isotherm $12^{\circ} \mathrm{C}(\mathrm{m})$, and g) oceanic Niño index (in red: El Niño event; in blue: La Niña 
event). The red dots represent the months with tuna samples. The grey lines and shadows give respectively the monthly means and standard deviations over the 6-month period. The black regression line represents the significant temporal trend.

\subsection{Drivers of the inter-annual variability of tuna $\mathrm{Hg}$ content}

For bigeye, yellowfin and skipjack respectively, the best models explained 74.4, 49.4 and $27.5 \%$ of deviance for $\log (\mathrm{Hg})$ and 29.3, 16 and 14.2\% of deviance for standardized $\mathrm{Hg}$ concentrations (Table 2; Figs. $5 \& \mathrm{~S} 2)$. For the three species, fish length appeared as the best stand-alone predictor of $\log (\mathrm{Hg})$, explaining 61.8, 49.4 and $21.3 \%$ of the deviance for bigeye, yellowfin and skipjack respectively. Considering standardized $\mathrm{Hg}$ concentrations (i.e. residuals from the length-based $\mathrm{Hg}$ models), muscle $\delta^{15} \mathrm{~N}$ values were found to be the best stand-alone predictor of $\mathrm{Hg}$ distribution for bigeye and yellowfin; but they were not selected in skipjack's best model. Generally, $\mathrm{Hg}$ concentrations were found to increase with decreasing $\delta^{15} \mathrm{~N}$ values. $\delta^{13} \mathrm{C}$ values were significant in the best models of both bigeye and skipjack with lower $\mathrm{Hg}$ concentrations related to decreasing $\delta^{13} \mathrm{C}$ values. SST was selected in the best model of yellowfin only, with response curve predicting lower $\mathrm{Hg}$ concentrations when SST increased. No other oceanographic variables were selected in the optimal models. 
(a) bigeye $(\mathrm{DE}=74.4 \%)$

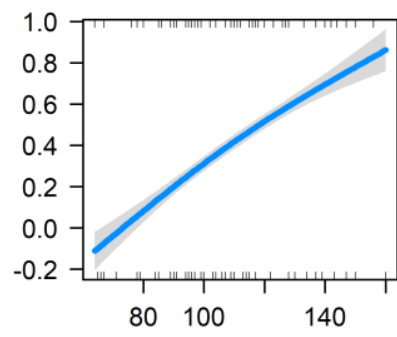

Fork length $(\mathrm{cm})$

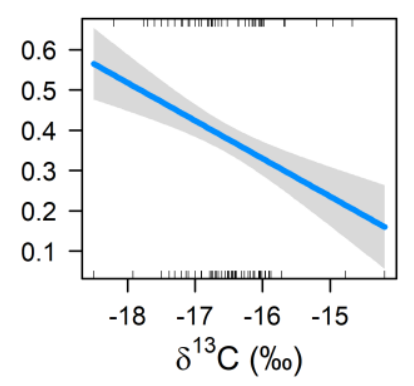

(b) yellowfin $(\mathrm{DE}=54.7 \%)$
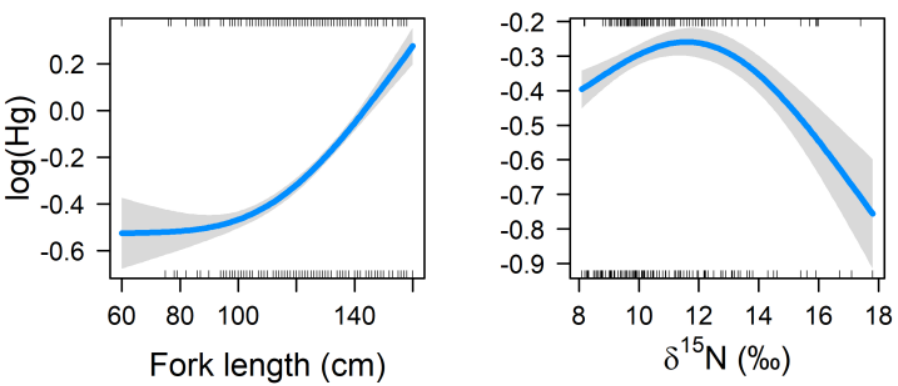

(c) skipjack (DE $=27.5 \%)$
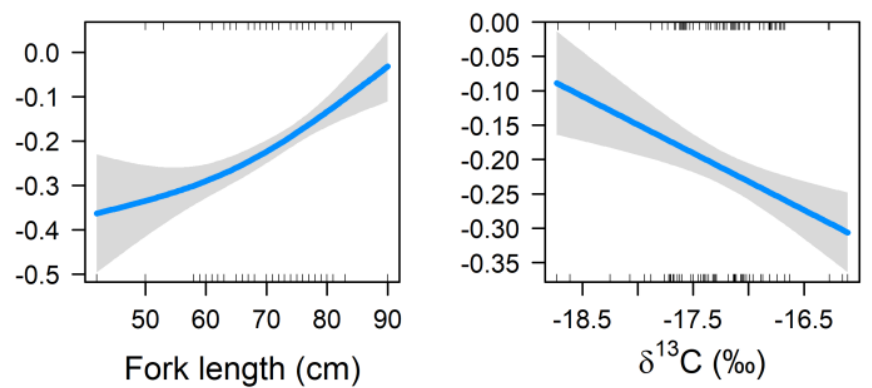
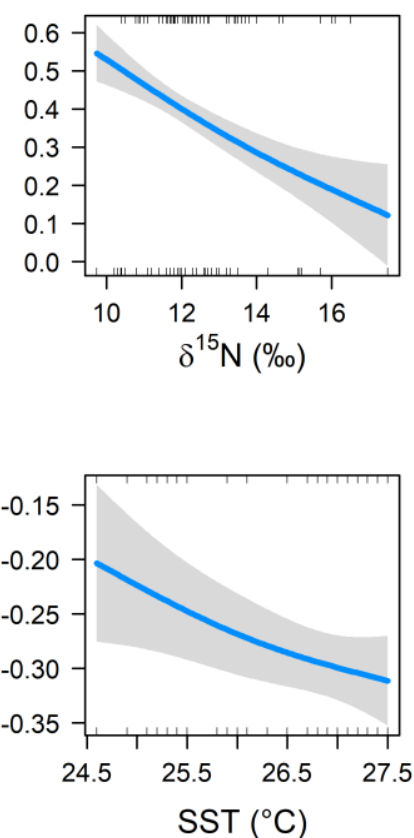

Figure 5: Results of the optimal generalized additive models (GAM) predicting $\log (\mathrm{Hg})$ in a) bigeye, b) yellowfin, and c) skipjack. The blue lines give the expected values while the grey bands show the confidence interval for the expected value. The ticks at the top and the bottom are the observed values' position associated respectively to positive and negative model residuals. DE: deviance explained.

Table 2: Results of the optimal generalized additive models (GAM) predicting $\log (\mathrm{Hg})$ and standardized $\mathrm{Hg}$ concentrations in bigeye, yellowfin and skipjack. n: number of tuna individuals; DE: deviance explained; $p$-value: statistics of the models

\begin{tabular}{ccccc}
\hline Species & Response variable & Explanatory variables & DE $(\%)$ & $\boldsymbol{p}$-value \\
\hline & Length & 61.8 & $<0.001$ \\
bigeye & $\log (\mathrm{Hg})$ & $\delta^{13} \mathrm{C}$ & 11.4 & $<0.001$ \\
& & $\delta^{15} \mathrm{~N}$ & 10.5 & $<0.001$
\end{tabular}




\begin{tabular}{|c|c|c|c|c|}
\hline & & Length $+\delta^{13} \mathrm{C}+\delta^{15} \mathrm{~N}$ & 74.4 & \\
\hline & & $\delta^{15} \mathrm{~N}$ & 17 & $<0.001$ \\
\hline & standardized $\mathrm{Hg}$ & $\delta^{13} \mathrm{C}$ & 8.6 & $<0.001$ \\
\hline & & $\delta^{15} \mathrm{~N}+\delta^{13} \mathrm{C}$ & 29.3 & \\
\hline \multirow{7}{*}{ yellowfin } & \multirow{4}{*}{$\log (\mathrm{Hg})$} & Length & 49.4 & $<0.001$ \\
\hline & & $\delta^{15} \mathrm{~N}$ & 13.2 & $<0.001$ \\
\hline & & SST & 0.34 & 0.027 \\
\hline & & Length $+\delta^{15} \mathrm{~N}+\mathrm{SST}$ & 54.7 & \\
\hline & \multirow{3}{*}{ standardized $\mathrm{Hg}$} & $\delta^{15} \mathrm{~N}$ & 12.4 & $<0.001$ \\
\hline & & SST & 2.31 & $<0.001$ \\
\hline & & $\delta^{15} \mathrm{~N}+\mathrm{SST}$ & 16.0 & \\
\hline \multirow{4}{*}{ skipjack } & \multirow{3}{*}{$\log (\mathrm{Hg})$} & Length & 21.3 & $<0.001$ \\
\hline & & $\delta^{13} \mathrm{C}$ & 9.3 & $<0.001$ \\
\hline & & Length $+\delta^{13} \mathrm{C}$ & 27.5 & \\
\hline & standardized $\mathrm{Hg}$ & $\delta^{13} \mathrm{C}$ & 14.2 & $<0.001$ \\
\hline
\end{tabular}

\subsection{Mercury concentrations and tuna $\delta^{15} \mathrm{~N}$ values in relation to baseline processes}

Standardized $\mathrm{Hg}$ concentrations and estimated phytoplankton $\delta^{15} \mathrm{~N}$ values were negatively correlated for bigeye and yellowfin $(p<0.05)$ while no significant linear relationship was found for skipjack (Fig. 6a). Conversely, tuna muscle $\delta^{15} \mathrm{~N}$ values were positively correlated to phytoplankton $\delta^{15} \mathrm{~N}$ estimates for the three species (Fig. 6b, p<0.05). For yellowfin samples analysed in AA-CSIA, standardized $\mathrm{Hg}$ was found to be negatively correlated to source amino acids (Sr-AA) $\delta^{15} \mathrm{~N}$ values, while both tuna muscle and estimated baseline $\delta^{15} \mathrm{~N}$ values were positively correlated to Sr-AA $\delta^{15} \mathrm{~N}$ values (Figs. $6 \mathrm{c}$, $6 \mathrm{~d} \& 6 \mathrm{e}$, all $p<0.05)$ 


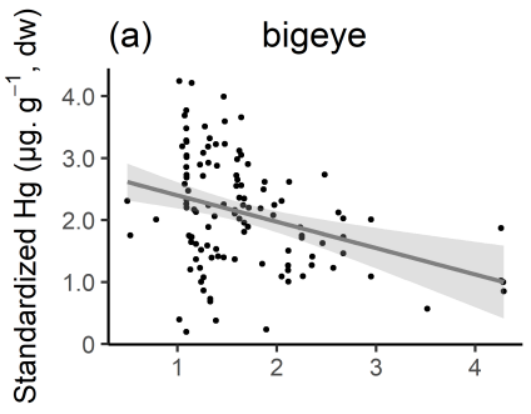

yellowfin
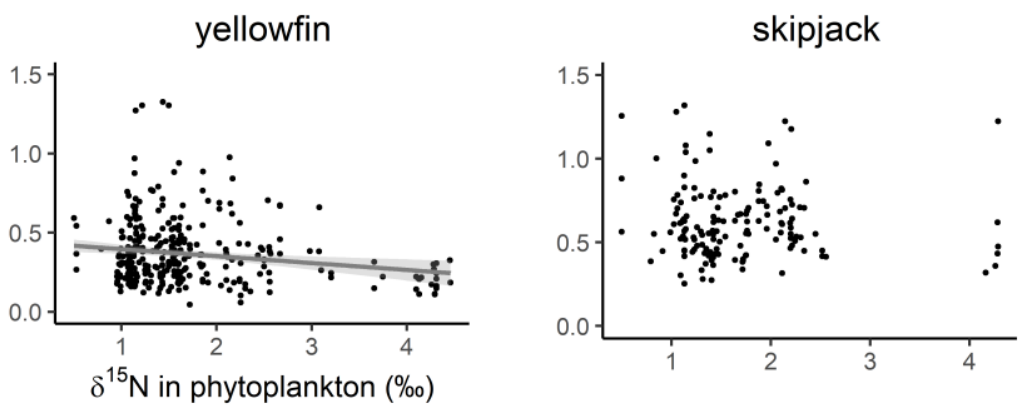

(b)
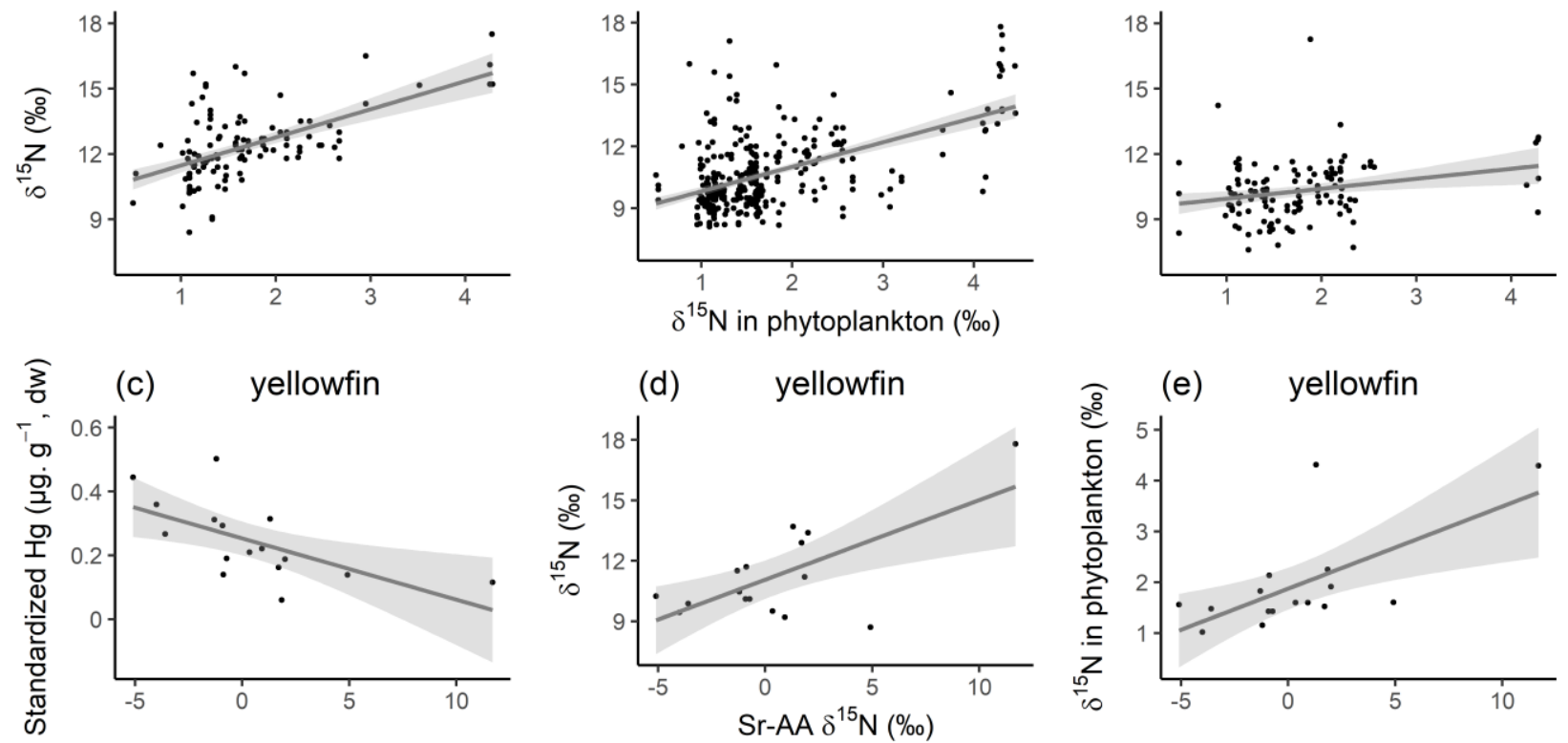

Figure 6: Relationships between a) standardized $\mathrm{Hg}$ concentrations $\left(\mu \mathrm{g} \cdot \mathrm{g}^{-1}, \mathrm{dw}\right.$ ) and estimated baseline phytoplankton $\delta^{15} \mathrm{~N}$ values (\%); and b) tuna muscle $\delta^{15} \mathrm{~N}$ values (\%) and estimated baseline phytoplankton $\delta^{15} \mathrm{~N}$ values (\%). In selected yellowfin samples analysed for AA-CSIA, relationships between c) standardized Hg concentrations $\left(\mu \mathrm{g} \cdot \mathrm{g}^{-1}, \mathrm{dw}\right)$ and $\mathrm{Sr}-$ AA $\delta^{15} \mathrm{~N}$ values; d) muscle $\delta^{15} \mathrm{~N}$ values (\%o) and Sr-AA $\delta^{15} \mathrm{~N}$ values (\%); and e) estimated baseline phytoplankton $\delta^{15} \mathrm{~N}$ values (\%) and $\mathrm{Sr}-\mathrm{AA} \delta^{15} \mathrm{~N}(\%)$. The lines represent the significant linear relationships between the two variables and the grey bands show the confidence intervals. 


\section{Discussion}

We report the first long-term temporal study of $\mathrm{Hg}$ concentrations in tropical commercial tuna from the south western Pacific Ocean. Contrary to existing temporal studies of tuna $\mathrm{Hg}$ content in the north Pacific Ocean (Hawaii, Drevnick et al., 2015) and in the north western Atlantic Ocean (Lee et al., 2016), our study revealed the absence of a significant long-term trend of $\mathrm{Hg}$ concentrations in tuna from the New Caledonia-Fiji region during the last two decades. Strong inter-annual variability of $\mathrm{Hg}$ concentrations was however found in all three tuna species and was mainly related to the variability in tuna sampled lengths among years and to biogeochemical processes occurring at the primary producer level.

\subsection{Mercury concentrations in tropical tuna}

Among the three species, only bigeye tuna exhibited $\mathrm{Hg}$ concentrations exceeding the food safety guideline of $1 \mu \mathrm{g} \cdot \mathrm{g}^{-1}$ (wet weight) (WHO and UNEP Chemicals, 2008), representing 32\% of the sampled specimens. Overall, most of these individuals $(86 \%)$ were bigger than $110 \mathrm{~cm}$. A few yellowfin were also above the food safety guideline but represented only $0.6 \%$ of the dataset. This illustrates the need to consider both tuna species and fish size when addressing recommendations in terms of food security regarding $\mathrm{Hg}$ content.

Relative differences of $\mathrm{Hg}$ concentration between the three studied tuna species in the south western Pacific Ocean were similar to those reported in the north eastern and north western Pacific Ocean (Blum et al., 2013; Choy et al., 2009; García-Hernández et al., 2007; Yamashita et al., 2005). The highest $\mathrm{Hg}$ content in bigeye compared to the two other species is presumably the result of three confounding factors: a higher TP for this species, a deeper vertical habitat facilitating its access to mesopelagic prey with enhanced $\mathrm{Hg}$ concentrations, and a longer lifespan (Choy et al., 2009; Houssard et al., 2019). The significant differences between species muscle $\delta^{15} \mathrm{~N}$ values could indeed suggest a 
slightly higher TP for bigeye compared to yellowfin and skipjack, as reported in the eastern Atlantic and the western Indian oceans (Sardenne et al., 2019, 2016). On the other hand, these differences of $\delta^{15} \mathrm{~N}$ values could also reflect distinct foraging habitat with bigeye occupying deeper habitats where prey are characterized by higher $\delta^{15} \mathrm{~N}$ values due to baseline effects (Hannides et al., 2013).

\subsection{Decadal stability of tuna mercury concentrations}

Our study revealed no significant long-term trend of $\mathrm{Hg}$ concentrations between 2001 and 2018 in the New Caledonia-Fiji region despite significant inter-annual variability (discussed separately below). As samples were collected opportunistically onboard fishing boats, it was not possible to perform our temporal analysis on the same number of samples for each species. The most complete and continuous yellowfin dataset illustrates the absence of a time trend over the 18 years, and similar finding applies to both skipjack and bigeye tuna.

Our observed stable long-term trends contrast with the estimated $\mathrm{Hg}$ increases of $3.8 \%$ annually reported in yellowfin tuna caught near Hawaii from 1971 to 2008 (Drevnick et al., 2015) and the mean annual decreasing rate of $19 \%$ from the 1990 s to the early 2000 s found in the Atlantic bluefin tuna from the north western Atlantic Ocean (Lee et al., 2016). In this later study, the authors suggested that lower $\mathrm{Hg}$ concentrations could be related to the reduction of anthropogenic $\mathrm{Hg}$ emission in North America, implying a direct link between $\mathrm{Hg}$ anthropogenic fluctuations and tuna $\mathrm{Hg}$ concentrations.

Our findings seem to confirm the fact that $\mathrm{Hg}$ bioaccumulation in fish do not necessarily follow the global suspected increase of anthropogenic $\mathrm{Hg}$ emissions to the atmosphere and instead suggest regional differences in oceanic $\mathrm{Hg}$ loads. The lack of long-term trend could be explained in part by the remoteness of our region, similar to most of the south western Pacific Ocean, which has low anthropogenic emissions and negligible loadings from anthropogenic sources on a total global emissions scale (Horowitz et al., 2017; UN Environment, 2019). The absence of detectable decadal 
trend in tuna $\mathrm{Hg}$ concentrations in this region mirrors the absence of consistent temporal trend in atmospheric $\mathrm{Hg}$ concentrations in the southern hemisphere (Slemr et al., 2020).

Our contrasted results with the two other temporal studies of $\mathrm{Hg}$ concentrations in tuna, located in the northern hemisphere, could be also related to distinct methodological approaches used to investigate the temporal trend over time. Drevnick et al. (2015) performed their temporal analysis on distinct, and highly heterogeneous datasets covering only three years (1971, 1998 and 2008) over a long study period (37 years), and with a limited number of individuals for the most recent period ( $\mathrm{n}=14$ in 2008). Conversely, we used a quasi-continuous long-term dataset analysed in the same laboratory from 2001 to 2018 with a larger sample size and more powerful statistical tools. Finally, unlike our study, no ecological proxies were available in these two other temporal studies of $\mathrm{Hg}$ content; therefore, it was not possible to investigate the potential confounding ecological contribution to the decreasing or increasing long-term trends of tuna $\mathrm{Hg}$ concentrations.

\subsection{Drivers of temporal variability of tuna $\mathrm{Hg}$ concentrations}

For the three tuna species, body length of sampled fish appeared to be the most important driver of inter-annual variability of $\mathrm{Hg}$ concentrations with highest and lowest $\mathrm{Hg}$ concentrations in the time series related to larger and smaller fish respectively (Figs. 2a, 2b \& 2c). This reflects the well-known bioaccumulative properties of $\mathrm{MeHg}$ in organisms (Adams, 2004; Cai et al., 2007; Houssard et al., 2019) and is mainly related to the variability in tuna sampled sizes among years. Therefore, lengthstandardized $\mathrm{Hg}$ concentrations are important to use when investigating factors governing $\mathrm{Hg}$ bioaccumulation in tuna. This strong relationship between length and $\mathrm{Hg}$ content $(61.8 \%, 49.4 \%$ and $21.3 \%$ for bigeye, yellowfin and skipjack respectively) explains the relatively low scores of our modelling approach for length-standardized $\mathrm{Hg}$ concentration as most of the variation is already explained by fish length. Furthermore, for yellowfin and skipjack, where the variance of bulk $\mathrm{Hg}$ 
concentrations is lower compared to bigeye, by extracting the residuals from the length-based $\mathrm{Hg}$ models to calculate standardized $\mathrm{Hg}$ concentrations, we consequently reduced these variances even more and therefore, the variability to be explained in our GAMs. Considering the ontogenetic dietary shift in bigeye and yellowfin (Sardenne et al., 2016), fitting GAMs on distinct fish length classes (e.g. small $\leq 100 \mathrm{~cm}$ vs large tuna $>100 \mathrm{~cm}$ ) would have been interesting to investigate differences among the main processes governing $\mathrm{Hg}$ methylation and $\mathrm{MeHg}$ bioaccumulation. Unfortunately, not enough data were available to do so.

Considering standardized $\mathrm{Hg}$ concentrations (i.e. residuals from length-based $\mathrm{Hg}$ models), inter-annual variability of $\mathrm{Hg}$ concentrations in bigeye and yellowfin best correlated with muscle $\delta^{15} \mathrm{~N}$ values, and our predictions showed generally higher $\mathrm{Hg}$ concentrations associated with lower muscle $\delta^{15} \mathrm{~N}$ values. In the literature, most studies found that $\mathrm{Hg}$ is strongly correlated to organism $\delta^{15} \mathrm{~N}$ values, yet through a positive relationship, reflecting $\mathrm{Hg}$ biomagnification along the pelagic food web (Cai et al., 2007; Teffer et al., 2014). Nevertheless, when exploring muscle $\delta^{15} \mathrm{~N}$ values at the species level, it is important to keep in mind that they result from trophic dynamics along the food web, but also from biogeochemical processes at the base of the ecosystem (baseline effects). Here, muscle $\delta^{15} \mathrm{~N}$ values were positively correlated to estimated baseline phytoplankton $\delta^{15} \mathrm{~N}$ values and $\mathrm{Sr}-\mathrm{AA} \delta^{15} \mathrm{~N}$ values, used to track baseline changes in nutrient sources and uptake. Therefore, temporal variations of muscle $\delta^{15} \mathrm{~N}$ values would predominantly reflect changes at the base of the food web. This could be related to the high levels of diazotrophy well documented in our study region (Bonnet et al., 2017; Garcia et al., 2007; Shiozaki et al., 2014) and characterized by low POM $\delta^{15} \mathrm{~N}$ values ( 1\%o). Atmospheric nitrogen deposition from pollution (which typically has $\delta^{15} \mathrm{~N}$ values ranging from -7 to $0 \%$ ) could also explain the low basal $\delta^{15} \mathrm{~N}$ values; yet as nitrogen emissions are supposed to be low in our study area compared to the north Pacific Ocean, this phenomenon is likely of less importance compared to diazotrophy (Gobel et al., 2013; Reay et al., 2008). Thereby, the response curves associated with muscle $\delta^{15} \mathrm{~N}$ values (i.e. higher $\mathrm{Hg}$ concentrations associated with lower $\delta^{15} \mathrm{~N}$ values and thus with higher 
diazotrophy) in our models may suggest that the nitrogen cycle and/or diazotrophy (i.e. baseline effects) are likely to drive $\mathrm{Hg}$ concentrations in the upper part of the oceanic pelagic food web, probably triggering $\mathrm{Hg}$ net methylation and bioavailability at the base of the food web during diazotroph blooms and/or their resulting remineralization. This finding is in line with the recent study by $\mathrm{Wu}$ et al. (2019) who revealed in a meta-analysis that bioconcentration (i.e. $\mathrm{MeHg}$ transfer from water into the base of the food web) was a better descriptor of fish $\mathrm{MeHg}$ concentrations than biomagnification in pelagic food web. The influence of the nitrogen cycle and/or diazotrophy on $\mathrm{Hg}$ concentrations seems to be also confirmed by the negative correlations found in this study between standardized $\mathrm{Hg}$ concentrations and both $\mathrm{Sr}-\mathrm{AA} \delta^{15} \mathrm{~N}$ values and estimated baseline $\delta^{15} \mathrm{~N}$ values.

The community structure and growth of primary producers, as inferred by tuna $\delta^{13} \mathrm{C}$ values, also seems to influence the observed inter-annual variability of $\mathrm{Hg}$ concentrations, particularly for both bigeye and skipjack tuna, with $\mathrm{Hg}$ concentrations predicted to decrease with increasing $\delta^{13} \mathrm{C}$ values. Here, $\delta^{13} \mathrm{C}$ values were the only ecological parameter showing a significant decline between 2001 and 2018. The same trends were found at the global scale and were attributed to a potential global shift of the phytoplankton community structure and/or physiology (Lorrain et al., 2020). The lack of a corresponding long-term $\mathrm{Hg}$ trend in our study may suggest that the carbon cycle is likely to impact $\mathrm{Hg}$ fate in oceans and tuna but to a lesser extent than the nitrogen cycle, and in particular diazotroph blooms.

As dinitrogen fixers typically thrive in warm and stratified waters, those conditions, more than the nitrogen cycle itself, could be linked to the $\mathrm{Hg}$ cycle. Recent model predictions made on Atlantic bluefin tuna show that increasing tissue $\mathrm{Hg}$ concentrations were related to rising seawater temperatures (Schartup et al., 2019). Furthermore, experimental studies on estuarine and freshwater fish have found that warmer temperatures enhanced MeHg bioaccumulation (Dijkstra et al., 2013; Maulvault et al., 2016). However, in this study SST was selected in the optimal model for yellowfin only, showing an opposing response curve to the above hypothesis, i.e. lower $\mathrm{Hg}$ concentrations in tuna related to higher 
SST. Our response curve for yellowfin is in agreement with Houssard et al. (2019) where Hg content was found to decrease spatially with increasing SST. Considering the potential impact of stratification, the depth of isotherm $12^{\circ} \mathrm{C}\left(\mathrm{D}_{\text {iso12, }}\right.$, which can be used as a proxy of the thermocline and thus stratification) was not selected in any of our optimal models. In Houssard et al. (2019), $\mathrm{D}_{\text {isol2 }}$ was found as the second main driver (after fish length) of the spatial variability of tuna $\mathrm{Hg}$ content with $\mathrm{Hg}$ concentrations enhanced in regions characterised by deeper thermoclines. These distinct results may suggest that the stand-alone temporal variability of the thermocline depth is not responsible for the inter-annual variations of $\mathrm{Hg}$ concentrations in tuna muscle. While discussing the impact of these environmental variables, it is worthwhile mentioning that we worked at a sub-regional scale where temporal variability is low compared to large spatial variability investigated in these other studies. For example, the ranges of our physical variables, especially for $\mathrm{D}_{\text {iso12 }}(428-451 \mathrm{~m})$, were reduced compared to the ones investigated in Houssard et al. (2019) ( $\mathrm{D}_{\text {iso12: }} 200-460 \mathrm{~m}$ ), which can explain their limited impact in our models.

Including complementary $\mathrm{Hg}$ data from the environment (i.e. $\mathrm{Hg}$ concentrations in seawater and total gaseous $\mathrm{Hg}$ ) in our modelling approach could have improved our model scores and helped characterize how $\mathrm{Hg}$ levels in tuna reflect $\mathrm{Hg}$ levels in water or in the atmosphere. Unfortunately, such data are scarce and no time series over the two last decades were available in our study area.

\subsection{Implications for global-scale monitoring of mercury}

With the adoption of the Minamata Convention in 2013, governments are asked to control and reduce anthropogenic $\mathrm{Hg}$ emissions which will require integrating biological tools into monitoring efforts so that the efficiency of political decisions can be tracked. Considering that tuna fisheries are among the world's most important fisheries, with a commercial value estimated at 41 billion \$US/y in 2012 (Macfadyen, 2016), quantifying nutritional risks along with benefits are becoming important when 
addressing food and nutritional security. Furthermore, knowing that oceans have undergone large physical and biogeochemical modifications in the last decades (e.g. surface warming, acidification, deoxygenation or changes in primary productivity) (Bopp et al., 2013; Kwiatkowski et al., 2017), it has become necessary to assess the predictive capacity of environmental variables on $\mathrm{Hg}$ methylation and bioaccumulation to understand potential climate-driven ecological changes.

With a continuous and long-term dataset, we revealed for the first time the absence of significant decadal trend of $\mathrm{Hg}$ concentrations in tropical tuna from the New Caledonia-Fiji region. This contrasts with the two other available temporal studies from distinct areas (Drevnick et al., 2015; Lee et al., 2016) and thus illustrates the complexity of the $\mathrm{Hg}$ cycle and the fact that $\mathrm{Hg}$ in tuna does not necessarily follow the suspected recent increasing $\mathrm{Hg}$ trends in global oceans, especially in the southern hemisphere. Our results however seem consistent with the remoteness of our study region in terms of low anthropogenic emissions, and thus seem to confirm the hypothesis of distinct hemispherical ocean patterns of $\mathrm{Hg}$ anthropogenic deposition.

Strong inter-annual variability was found in the three tuna species and was mainly due to fish length variability among samples. This suggests the importance of using a fish length-based approach to address the question of $\mathrm{Hg}$ spatial and temporal trends in tuna even at small (e.g. sub-regional) scales. This includes accounting for different types of fishing gear (e.g. purse seine and longline) employed since fishing gears are known to preferentially select certain tuna fish sizes.

Finally, our novel complementary investigation of baseline and trophic ecological tracers highlights i) no significant decadal change in tuna TP during this 18 year period, and ii) the influence of baseline processes for bigeye and yellowfin, related to the nitrogen cycle and/or diazotrophy, possibly enhancing $\mathrm{Hg}$ methylation and/or MeHg bioavailability at the base of the food web. Knowing that the largest bioaccumulation step of $\mathrm{MeHg}$ is likely to occur between the water compartment and unicellular planktonic organisms - relative to trophic amplification processes - more attention needs to 
be paid to ecological and physiological processes occurring at the base of marine ecosystems to better capture $\mathrm{Hg}$ spatio-temporal trends at the top of the ocean food webs.

Lastly, our study emphasizes the need for more systematic collection of $\mathrm{Hg}$ and stable isotope data in different marine reservoirs, including $\mathrm{iHg}$ in the water column, from both hemispheres to compare $\mathrm{MeHg}$ production, degradation and bioaccumulation in oceans at a global scale. 


\section{Declaration of competing interests}

The authors declare that they have no known competing financial interests or personal relationships that could have appeared to influence the work reported in this paper.

\section{Acknowledgments}

We thank the large team of observers and supervisors from the National Observer Programs of the Pacific Island Countries and Territories and FSM Arrangement Observer Program who collected the tuna samples. We are grateful to the WCPFC (Western and Central Pacific Fisheries Commission) Tuna Tissue Bank and the SPC (Pacific Community) Pacific Marine Specimen Bank which gave us access to the tuna tissue samples. We thank the LAMA laboratory, especially Jean-Louis Duprey and Stéphanie Berne for $\mathrm{Hg}$ analyses, as well as the Union College Stable Isotope Laboratory team Anouk Verheyden, Sarah Katz, and Madelyn Miller. We also thank Pablo Brosset for his helpful discussions. Finally we thank the four anonymous referees for their remarks and suggestions that substantially improved the manuscript. Funding was provided by the Pacific Fund VACOPA project and ANR-17CE34-0010 MERTOX from the French Agence Nationale de la Recherche. The U.S. National Science Foundation funded Union College's isotope ratio mass spectrometer and peripherals (NSF-MRI \#1229258). 


\section{References}

Adams, D.H., 2004. Total mercury levels in tunas from offshore waters of the Florida Atlantic coast. Marine Pollution Bulletin 49, 659-663. https://doi.org/10.1016/j.marpolbul.2004.06.005

Atwell, L., Hobson, K.A., Welch, H.E., 1998. Biomagnification and bioaccumulation of mercury in an arctic marine food web: insights from stable nitrogen isotope analysis. Can. J. Fish. Aquat. Sci. 55, 1114 1121. https://doi.org/10.1139/f98-001

Behrenfeld, M.J., Falkowski, P.G., 1997. Photosynthetic rates derived from satellite-based chlorophyll concentration. Limnology and Oceanography 42, 1-20. https://doi.org/10.4319/lo.1997.42.1.0001

Bell, J.D., Allain, V., Allison, E.H., Andréfouët, S., Andrew, N.L., Batty, M.J., Blanc, M., Dambacher, J.M., Hampton, J., Hanich, Q., Harley, S., Lorrain, A., McCoy, M., McTurk, N., Nicol, S., Pilling, G., Point, D., Sharp, M.K., Vivili, P., Williams, P., 2015. Diversifying the use of tuna to improve food security and public health in Pacific Island countries and territories. Marine Policy 51, 584-591. https://doi.org/10.1016/j.marpol.2014.10.005

Bell, J.D., Reid, C., Batty, M.J., Allison, E.H., Lehodey, P., Rodwell, L., Pickering, T.D., Gillett, R., Johnson, J.E., Hobday, A.J., Demmke, A., 2011. Implications of climate change for contributions by fisheries and aquaculture to Pacific Island economies and communities, in: Vulnerability of Tropical Pacific Fisheries and Aquaculture to Climate Change: Summary for Pacific Island Countries and Territories. Secretariat of the Pacific Community, Noumea, New Caledonia, p. 71.

Blum, J.D., Popp, B.N., Drazen, J.C., Anela Choy, C., Johnson, M.W., 2013. Methylmercury production below the mixed layer in the North Pacific Ocean. Nature Geoscience 6, 879-884. https://doi.org/10.1038/ngeo1918

Bonnet, S., Caffin, M., Berthelot, H., Moutin, T., 2017. Hot spot of N2 fixation in the western tropical South Pacific pleads for a spatial decoupling between N2 fixation and denitrification. Proc Natl Acad Sci USA 114, E2800-E2801. https://doi.org/10.1073/pnas.1619514114

Bopp, L., Resplandy, L., Orr, J.C., Doney, S.C., Dunne, J.P., Gehlen, M., Halloran, P., Heinze, C., Ilyina, T., Séférian, R., Tjiputra, J., Vichi, M., 2013. Multiple stressors of ocean ecosystems in the 21st century: projections with CMIP5 models. Biogeosciences 10, 6225-6245. https://doi.org/10.5194/bg-10-62252013

Bradley, C.J., Wallsgrove, N.J., Choy, C.A., Drazen, J.C., Hetherington, E.D., Hoen, D.K., Popp, B.N., 2015. Trophic position estimates of marine teleosts using amino acid compound specific isotopic analysis. Limnology and Oceanography: Methods 13, 476-493. https://doi.org/10.1002/lom3.10041

Brind'Amour, A., Mahévas, S., Legendre, P., Bellanger, L., 2018. Application of Moran Eigenvector Maps (MEM) to irregular sampling designs. Spatial Statistics 26, 56-68. https://doi.org/10.1016/j.spasta.2018.05.004

Burnham, K.P., Anderson, D.R., 2004. Multimodel Inference: Understanding AIC and BIC in Model Selection. Sociological Methods \& Research 33, 261-304. https://doi.org/10.1177/0049124104268644

Cai, Y., Rooker, J.R., Gill, G.A., Turner, J.P., 2007. Bioaccumulation of mercury in pelagic fishes from the northern Gulf of Mexico. Canadian Journal of Fisheries and Aquatic Sciences 64, 458-469. https://doi.org/10.1139/f07-017

Chouvelon, T., Brach-Papa, C., Auger, D., Bodin, N., Bruzac, S., Crochet, S., Degroote, M., Hollanda, S.J., Hubert, C., Knoery, J., Munschy, C., Puech, A., Rozuel, E., Thomas, B., West, W., Bourjea, J., Nikolic, N., 2017. Chemical contaminants (trace metals, persistent organic pollutants) in albacore tuna from western Indian and south-eastern Atlantic Oceans: Trophic influence and potential as tracers of populations. Science of The Total Environment 596-597, 481-495. https://doi.org/10.1016/j.scitotenv.2017.04.048

Choy, C.A., Popp, B.N., Hannides, C.C.S., Drazen, J.C., 2015. Trophic structure and food resources of epipelagic and mesopelagic fishes in the North Pacific Subtropical Gyre ecosystem inferred from nitrogen isotopic compositions: Trophic structure of pelagic fishes. Limnology and Oceanography 60, 1156-1171. https://doi.org/10.1002/lno.10085 
Choy, C.A., Popp, B.N., Kaneko, J.J., Drazen, J.C., 2009. The influence of depth on mercury levels in pelagic fishes and their prey. Proceedings of the National Academy of Sciences 106, 13865-13869. https://doi.org/10.1073/pnas.0900711106

Cravatte, S., Kestenare, E., Eldin, G., Ganachaud, A., Lefèvre, J., Marin, F., Menkes, C., Aucan, J., 2015. Regional circulation around New Caledonia from two decades of observations. Journal of Marine Systems 148, 249-271. https://doi.org/10.1016/j.jmarsys.2015.03.004

Dale, J., Wallsgrove, N., Popp, B., Holland, K., 2011. Nursery habitat use and foraging ecology of the brown stingray Dasyatis lata determined from stomach contents, bulk and amino acid stable isotopes. Mar. Ecol. Prog. Ser. 433, 221-236. https://doi.org/10.3354/meps09171

Di Bella, G., Potortì, A.G., Lo Turco, V., Bua, D., Licata, P., Cicero, N., Dugo, G., 2015. Trace elements in Thunnus Thynnus from Mediterranean Sea: benefit-risk assessment for consumer. Food Additives \& Contaminants: Part B 8, 175-181. https://doi.org/10.1080/19393210.2015.1030347

Dijkstra, J.A., Buckman, K.L., Ward, D., Evans, D.W., Dionne, M., Chen, C.Y., 2013. Experimental and Natural Warming Elevates Mercury Concentrations in Estuarine Fish. PLoS ONE 8, e58401. https://doi.org/10.1371/journal.pone.0058401

Dray, S., Legendre, P., Peres-Neto, P.R., 2006. Spatial modelling: a comprehensive framework for principal coordinate analysis of neighbour matrices (PCNM). Ecological Modelling 196, 483-493. https://doi.org/10.1016/j.ecolmodel.2006.02.015

Drevnick, P.E., Lamborg, C.H., Horgan, M.J., 2015. Increase in mercury in Pacific yellowfin tuna: Mercury in yellowfin tuna. Environmental Toxicology and Chemistry 34, 931-934. https://doi.org/10.1002/etc.2883

FAO (Ed.), 2018. The state of world fisheries and aquaculture 2018 - Meeting the sustainable development goals. Rome.

Fry, B., 2006. Stable isotope ecology. Springer, New York, NY.

Garcia, N., Raimbault, P., Sandroni, V., 2007. Seasonal nitrogen fixation and primary production in the Southwest Pacific: nanoplankton diazotrophy and transfer of nitrogen to picoplankton organisms. Mar. Ecol. Prog. Ser. 343, 25-33. https://doi.org/10.3354/meps06882

García-Hernández, J., Cadena-Cárdenas, L., Betancourt-Lozano, M., García-De-La-Parra, L.M., García-Rico, L., Márquez-Farías, F., 2007. Total mercury content found in edible tissues of top predator fish from the Gulf of California, Mexico. Toxicological \& Environmental Chemistry 89, 507-522. https://doi.org/10.1080/02772240601165594

Gillett, R., 2009. Fisheries in the Economies of the Pacific Island Countries and Territories. Asian Development Bank.

Gobel, A.R., Altieri, K.E., Peters, A.J., Hastings, M.G., Sigman, D.M., 2013. Insights into anthropogenic nitrogen deposition to the North Atlantic investigated using the isotopic composition of aerosol and rainwater nitrate: NITRATE ISOTOPES IN MARINE AEROSOLS. Geophys. Res. Lett. 40, 59775982. https://doi.org/10.1002/2013GL058167

Guinehut, S., Dhomps, A.-L., Larnicol, G., Traon, P.-Y.L., 2012. High resolution 3-D temperature and salinity fields derived from in situ and satellite observations. Ocean Science 8, 845-857. https://doi.org/10.5194/os-8-845-2012

Hannides, C.C.S., Popp, B.N., Choy, C.A., Drazen, J.C., 2013. Midwater zooplankton and suspended particle dynamics in the North Pacific Subtropical Gyre: A stable isotope perspective. Limnology and Oceanography 58, 1931-1946. https://doi.org/10.4319/lo.2013.58.6.1931

Hayes, J.M., Freeman, K.H., Popp, B.N., Hoham, C.H., 1990. Compound-specific isotopic analyses: A novel tool for reconstruction of ancient biogeochemical processes. Organic Geochemistry, Proceedings of the 14th International Meeting on Organic Geochemistry 16, 1115-1128. https://doi.org/10.1016/0146-6380(90)90147-R

Hintelmann, H., 2010. Organomercurials. Their Formation and Pathways in the Environment, in: Organometallics in Environment and Toxicology: Metal Ions in Life Sciences. pp. 365-401. https://doi.org/10.1039/9781849730822-00365

Horowitz, H.M., Jacob, D.J., Zhang, Y., Dibble, T.S., Slemr, F., Amos, H.M., Schmidt, J.A., Corbitt, E.S., Marais, E.A., Sunderland, E.M., 2017. A new mechanism for atmospheric mercury redox chemistry: implications for the global mercury budget. Atmospheric Chemistry and Physics 17.

https://doi.org/10.5194/acp-17-6353-2017 
Houssard, P., Lorrain, A., Tremblay-Boyer, L., Allain, V., Graham, B.S., Menkes, C.E., Pethybridge, H., Couturier, L.I.E., Point, D., Leroy, B., Receveur, A., Hunt, B.P.V., Vourey, E., Bonnet, S., Rodier, M., Raimbault, P., Feunteun, E., Kuhnert, P.M., Munaron, J.-M., Lebreton, B., Otake, T., Letourneur, Y., 2017. Trophic position increases with thermocline depth in yellowfin and bigeye tuna across the Western and Central Pacific Ocean. Progress in Oceanography 154, 49-63. https://doi.org/10.1016/j.pocean.2017.04.008

Houssard, P., Point, D., Tremblay-Boyer, L., Allain, V., Pethybridge, H., Masbou, J., Ferriss, B.E., Baya, P.A., Lagane, C., Menkes, C.E., Letourneur, Y., Lorrain, A., 2019. A Model of Mercury Distribution in Tuna from the Western and Central Pacific Ocean: Influence of Physiology, Ecology and Environmental Factors. Environmental Science \& Technology 53, 1422-1431. https://doi.org/10.1021/acs.est.8b06058

Kojadinovic, J., Potier, M., Le Corre, M., Cosson, R.P., Bustamante, P., 2006. Mercury content in commercial pelagic fish and its risk assessment in the Western Indian Ocean. Science of The Total Environment 366, 688-700. https://doi.org/10.1016/j.scitotenv.2006.02.006

Kwiatkowski, L., Bopp, L., Aumont, O., Ciais, P., Cox, P.M., Laufkötter, C., Li, Y., Séférian, R., 2017. Emergent constraints on projections of declining primary production in the tropical oceans. Nature Clim Change 7, 355-358. https://doi.org/10.1038/nclimate3265

Kwon, S.Y., Blum, J.D., Madigan, D.J., Block, B.A., Popp, B.N., 2016. Quantifying mercury isotope dynamics in captive Pacific bluefin tuna (Thunnus orientalis). Elem Sci Anth 4, 000088. https://doi.org/10.12952/journal.elementa.000088

Lamborg, C.H., Hammerschmidt, C.R., Bowman, K.L., Swarr, G.J., Munson, K.M., Ohnemus, D.C., Lam, P.J., Heimbürger, L.-E., Rijkenberg, M.J.A., Saito, M.A., 2014. A global ocean inventory of anthropogenic mercury based on water column measurements. Nature 512, 65-68. https://doi.org/10.1038/nature13563

Le Borgne, R., Allain, V., Griffiths, S.P., Matear, R.J., McKinnon, A.D., Richardson, A.J., Young, J.W., 2011. Vulnerability of open ocean food webs in the tropical Pacific to climate change, in: Vulnerability of Tropical Pacific Fisheries and Aquaculture to Climate Change. Secretariat of the Pacific Community, New Caledonia, pp. 189-249.

Lee, C.-S., Lutcavage, M.E., Chandler, E., Madigan, D.J., Cerrato, R.M., Fisher, N.S., 2016. Declining Mercury Concentrations in Bluefin Tuna Reflect Reduced Emissions to the North Atlantic Ocean. Environmental Science \& Technology 50, 12825-12830. https://doi.org/10.1021/acs.est.6b04328

Legendre, P., Gauthier, O., 2014. Statistical methods for temporal and space-time analysis of community composition data. Proceedings of the Royal Society B: Biological Sciences 281, 2013272820132728. https://doi.org/10.1098/rspb.2013.2728

Logan, J.M., Jardine, T.D., Miller, T.J., Bunn, S.E., Cunjak, R.A., Lutcavage, M.E., 2008. Lipid corrections in carbon and nitrogen stable isotope analyses: comparison of chemical extraction and modelling methods. Journal of Animal Ecology 77, 838-846. https://doi.org/10.1111/j.1365-2656.2008.01394.x

Lorrain, A., Clavier, J., Thébault, J., Tremblay-Boyer, L., Houlbrèque, F., Amice, E., Le Goff, M., Chauvaud, L., 2015a. Variability in diel and seasonal in situ metabolism of the tropical gastropod Tectus niloticus. Aquat. Biol. 23, 167-182. https://doi.org/10.3354/ab00618

Lorrain, A., Graham, B.S., Popp, B.N., Allain, V., Olson, R.J., Hunt, B.P.V., Potier, M., Fry, B., GalvánMagaña, F., Menkes, C.E.R., Kaehler, S., Ménard, F., 2015b. Nitrogen isotopic baselines and implications for estimating foraging habitat and trophic position of yellowfin tuna in the Indian and Pacific Oceans. Deep Sea Research Part II: Topical Studies in Oceanography 113, 188-198. https://doi.org/10.1016/j.dsr2.2014.02.003

Lorrain, A., Pethybridge, H., Cassar, N., Receveur, A., Allain, V., Bodin, N., Bopp, L., Choy, C.A., Duffy, L., Fry, B., Goñi, N., Graham, B.S., Hobday, A.J., Logan, J.M., Ménard, F., Menkes, C.E., Olson, R.J., Pagendam, D.E., Point, D., Revill, A.T., Somes, C.J., Young, J.W., 2020. Trends in tuna carbon isotopes suggest global changes in pelagic phytoplankton communities. Glob Change Biol 26, 458 470. https://doi.org/10.1111/gcb.14858

Macfadyen, G., 2016. Study of the global estimate of the value of tuna fisheries - Phase 3 Report. Poseidon Aquatic Resource Management Ltd.

Madigan, D.J., Litvin, S.Y., Popp, B.N., Carlisle, A.B., Farwell, C.J., Block, B.A., 2012. Tissue Turnover Rates and Isotopic Trophic Discrimination Factors in the Endothermic Teleost, Pacific Bluefin Tuna (Thunnus orientalis). PLOS ONE 7, e49220. https://doi.org/10.1371/journal.pone.0049220 
Maulvault, A.L., Custódio, A., Anacleto, P., Repolho, T., Pousão, P., Nunes, M.L., Diniz, M., Rosa, R., Marques, A., 2016. Bioaccumulation and elimination of mercury in juvenile seabass ( Dicentrarchus labrax ) in a warmer environment. Environmental Research 149, 77-85. https://doi.org/10.1016/j.envres.2016.04.035

Mergler, D., Anderson, H.A., Chan, L.H.M., Mahaffey, K.R., Murray, M., Sakamoto, M., Stern, A.H., 2007. Methylmercury Exposure and Health Effects in Humans: A Worldwide Concern. AMBIO: A Journal of the Human Environment 36, 3-11. https://doi.org/10.1579/00447447(2007)36[3:MEAHEI]2.0.CO;2

Nicklisch, S.C.T., Bonito, L.T., Sandin, S., Hamdoun, A., 2017. Mercury levels of yellowfin tuna (Thunnus albacares) are associated with capture location. Environmental Pollution 229, 87-93. https://doi.org/10.1016/j.envpol.2017.05.070

Ordiano-Flores, A., Galván-Magaña, F., Rosiles-Martínez, R., 2011. Bioaccumulation of Mercury in Muscle Tissue of Yellowfin Tuna, Thunnus albacares, of the Eastern Pacific Ocean. Biological Trace Element Research 144, 606-620. https://doi.org/10.1007/s12011-011-9136-4

Ordiano-Flores, A., Rosíles-Martínez, R., Galván-Magaña, F., 2012. Biomagnification of mercury and its antagonistic interaction with selenium in yellowfin tuna Thunnus albacares in the trophic web of Baja California Sur, Mexico. Ecotoxicology and Environmental Safety 86, 182-187. https://doi.org/10.1016/j.ecoenv.2012.09.014

Pirrone, N., Cinnirella, S., Feng, X., Finkelman, R.B., Friedli, H.R., Leaner, J., Mason, R., Mukherjee, A.B., Stracher, G.B., Streets, D.G., Telmer, K., 2010. Global mercury emissions to the atmosphere from anthropogenic and natural sources. Atmos. Chem. Phys. 10, 5951-5964. https://doi.org/10.5194/acp10-5951-2010

Popp, B.N., Graham, B.S., Olson, R.J., Hannides, C.C.S., Lott, M.J., López-Ibarra, G.A., Galván-Magaña, F., Fry, B., 2007. Insight into the Trophic Ecology of Yellowfin Tuna, Thunnus albacares, from Compound-Specific Nitrogen Isotope Analysis of Proteinaceous Amino Acids. Terrestrial Ecology 1, 173-190.

R Core Team, 2018. R: A language and environment for statistical computing; 2015. Vienna, Austria.

Reay, D.S., Dentener, F., Smith, P., Grace, J., Feely, R.A., 2008. Global nitrogen deposition and carbon sinks. Nature Geosci 1, 430-437. https://doi.org/10.1038/ngeo230

Reynolds, R.W., Rayner, N.A., Smith, T.M., Stokes, D.C., Wang, W., 2002. An Improved In Situ and Satellite SST Analysis for Climate. J. Climate 15, 1609-1625. https://doi.org/10.1175/15200442(2002)015<1609:AIISAS>2.0.CO;2

Sardenne, F., Bodin, N., Chassot, E., Amiel, A., Fouché, E., Degroote, M., Hollanda, S., Pethybridge, H., Lebreton, B., Guillou, G., Ménard, F., 2016. Trophic niches of sympatric tropical tuna in the Western Indian Ocean inferred by stable isotopes and neutral fatty acids. Progress in Oceanography 146, 75 88. https://doi.org/10.1016/j.pocean.2016.06.001

Sardenne, F., Diaha, N.C., Amandé, M.J., Zudaire, I., Couturier, L.I.E., Metral, L., Le Grand, F., Bodin, N., 2019. Seasonal habitat and length influence on the trophic niche of co-occurring tropical tunas in the eastern Atlantic Ocean. Canadian Journal of Fisheries and Aquatic Sciences 76, 69-80. https://doi.org/10.1139/cjfas-2017-0368

Schartup, A.T., Thackray, C.P., Qureshi, A., Dassuncao, C., Gillespie, K., Hanke, A., Sunderland, E.M., 2019. Climate change and overfishing increase neurotoxicant in marine predators. Nature 1-3. https://doi.org/10.1038/s41586-019-1468-9

Selin, N.E., Jacob, D.J., Park, R.J., Yantosca, R.M., Strode, S., Jaeglé, L., Jaffe, D., 2007. Chemical cycling and deposition of atmospheric mercury: Global constraints from observations. Journal of Geophysical Research 112. https://doi.org/10.1029/2006JD007450

Selin, N.E., Jacob, D.J., Yantosca, R.M., Strode, S., Jaeglé, L., Sunderland, E.M., 2008. Global 3-D landocean-atmosphere model for mercury: Present-day versus preindustrial cycles and anthropogenic enrichment factors for deposition. Global Biogeochemical Cycles 22, 13. https://doi.org/10.1029/2007GB003040

Shiozaki, T., Kodama, T., Furuya, K., 2014. Large-scale impact of the island mass effect through nitrogen fixation in the western South Pacific Ocean. Geophysical Research Letters 41, 2907-2913. https://doi.org/10.1002/2014GL059835

Sirot, V., Leblanc, J.-C., Margaritis, I., 2012. A risk-benefit analysis approach to seafood intake to determine optimal consumption. Br J Nutr 107, 1812-1822. https://doi.org/10.1017/S0007114511005010 
Slemr, F., Martin, L., Labuschagne, C., Mkololo, T., Angot, H., Magand, O., Dommergue, A., Garat, P., Ramonet, M., Bieser, J., 2020. Atmospheric mercury in the Southern Hemisphere - Part 1: Trend and inter-annual variations in atmospheric mercury at Cape Point, South Africa, in 2007-2017, and on Amsterdam Island in 2012-2017. Atmos. Chem. Phys. 20, 7683-7692. https://doi.org/10.5194/acp20-7683-2020

Somes, C.J., Oschlies, A., 2015. On the influence of "non-Redfield" dissolved organic nutrient dynamics on the spatial distribution of $\mathrm{N} 2$ fixation and the size of the marine fixed nitrogen inventory. Global Biogeochemical Cycles 29, 973-993. https://doi.org/10.1002/2014GB005050

Somes, C.J., Schmittner, A., Galbraith, E.D., Lehmann, M.F., Altabet, M.A., Montoya, J.P., Letelier, R.M., Mix, A.C., Bourbonnais, A., Eby, M., 2010. Simulating the global distribution of nitrogen isotopes in the ocean. Global Biogeochem. Cycles 24, n/a-n/a. https://doi.org/10.1029/2009GB003767

Somes, C.J., Schmittner, A., Muglia, J., Oschlies, A., 2017. A Three-Dimensional Model of the Marine Nitrogen Cycle during the Last Glacial Maximum Constrained by Sedimentary Isotopes. Frontiers in Marine Science 4. https://doi.org/10.3389/fmars.2017.00108

Sunderland, E.M., 2007. Mercury Exposure from Domestic and Imported Estuarine and Marine Fish in the U.S. Seafood Market. Environmental Health Perspectives 115, 235-242. https://doi.org/10.1289/ehp.9377

Sunderland, E.M., Krabbenhoft, D.P., Moreau, J.W., Strode, S.A., Landing, W.M., 2009. Mercury sources, distribution, and bioavailability in the North Pacific Ocean: Insights from data and models. Global Biogeochemical Cycles 23, 14. https://doi.org/10.1029/2008GB003425

Teffer, A.K., Staudinger, M.D., Taylor, D.L., Juanes, F., 2014. Trophic influences on mercury accumulation in top pelagic predators from offshore New England waters of the northwest Atlantic Ocean. Marine Environmental Research 101, 124-134. https://doi.org/10.1016/j.marenvres.2014.09.008

Tesdal, J.-E., Galbraith, E.D., Kienast, M., 2013. Nitrogen isotopes in bulk marine sediment: linking seafloor observations with subseafloor records. Biogeosciences 10, 101-118. https://doi.org/10.5194/bg-10$101-2013$

UN Environment, 2019. Global mercury assessment 2018.

Williams, P., Reid, C., 2018. Overview of tuna fisheries in the WCPO including economic conditions - 2017. Presented at the WCPFC - TCC14 - 2018, Majuro, Republic of Marshall Islands, p. 68.

Wood, S., Wood, M.S., 2015. Package "mgcv". R package version (No. 1.8-28).

World Health Organization, UNEP Chemicals, 2008. Guidance for identifying populations at risk from mercury exposure. UNEP DTIE Chemicals Branch and WHO Department of Food Safety, Zoonoses and Foodborne Diseases, Geneva, Switzerland.

Wu, P., Kainz, M.J., Bravo, A.G., Åkerblom, S., Sonesten, L., Bishop, K., 2019. The importance of bioconcentration into the pelagic food web base for methylmercury biomagnification: A metaanalysis. Science of The Total Environment 646, 357-367. https://doi.org/10.1016/j.scitotenv.2018.07.328

Yamashita, Y., Omura, Y., Okazaki, E., 2005. Total mercury and methylmercury levels in commercially important fishes in Japan. Fisheries Science 71, 1029-1035. https://doi.org/10.1111/j.14442906.2005.01060.x

Zuur, A.F., Ieno, E.N., Elphick, C.S., 2010. A protocol for data exploration to avoid common statistical problems: Data exploration. Methods in Ecology and Evolution 1, 3-14. https://doi.org/10.1111/j.2041-210X.2009.00001.x 